\title{
The Sierra Ballena Shear Zone in the southernmost Dom Feliciano Belt (Uruguay): evolution, kinematics, and deformation conditions
}

\author{
Pedro Oyhantçabal · Siegfried Siegesmund • \\ Klaus Wemmer · Paul Layer
}

Received: 12 August 2008/ Accepted: 10 May 2009/Published online: 26 May 2009

(C) Springer-Verlag 2009

\begin{abstract}
The Sierra Ballena Shear Zone (SBSZ) is part of a high-strain transcurrent system that divides the Neoproterozoic Dom Feliciano Belt of South America into two different domains. The basement on both sides of the SBSZ shows a deformation stage preceding that of the transcurrent deformation recognized as a high temperature mylonitic foliation associated with migmatization. Grain boundary migration and fluid-assisted grain boundary diffusion enhanced by partial melting were the main deformation mechanisms associated with this foliation. Age estimate of this episode is $>658 \mathrm{Ma}$. The second stage corresponds to the start of transpressional deformation and the nucleation and development of the SBSZ. During this stage, pure shear dominates the deformation, and is characterized by the development of conjugate dextral and sinistral shear zones and the emplacement of syntectonic granites. This event dates to $658-600 \mathrm{Ma}$ based on the age of these intrusions. The third stage was a second
\end{abstract}

\footnotetext{
P. Oyhantçabal $(\square)$

Departamento de Geología, Facultad de Ciencias,

Universidad de la República, Iguá 4225,

C.P. 11400 Montevideo, Uruguay

e-mail: oyhantca@fcien.edu.uy; oyhantca@gmail.com

S. Siegesmund · K. Wemmer

Geoscience Centre of the Georg-August University Göttingen,

Goldschmidtstr. 3, 37077 Göttingen, Germany

e-mail: ssieges@gwdg.de

K. Wemmer

e-mail: kwemmer@gwdg.de

P. Layer

Geophysical Institute, University of Alaska,

Fairbanks, AK 99775, USA

e-mail: player@gi.alaska.edu
}

transpressional event at about 586 to $<560 \mathrm{Ma}$ that was associated with the emplacement of porphyry dikes and granites that show evidence of flattening. Deformation in the SBSZ took place, during the late stages, under regional low-grade conditions, as indicated by the metamorphic paragenesis in the supracrustals of the country rocks. Granitic mylonites show plastic deformation of quartz and brittle behavior of feldspar. A transition from magmatic to solid-state microstructures is also frequently observed in syntectonic granites. Mylonitic porphyries and quartz mylonites resulted from the deformation of alkaline porphyries and quartz veins emplaced in the shear zone. Quartz veins reflect the release of silica associated with the breakdown of feldspar to white mica during the evolution of the granitic mylonites to phyllonites, which resulted in shear zone weakening. Quartz microstructures characteristic of the transition between regime 2 and regime 3 , grain boundary migration and incipient recrystallization in feldspar indicate deformation under lower amphibolite to upper greenschist conditions $\left(550-400^{\circ} \mathrm{C}\right)$. On the other hand, the mylonitic porphyries display evidence of feldspar recrystallization suggesting magmatic or high- $\mathrm{T}$ solid-state deformation during cooling of the dikes.

Keywords Brasiliano - Pan-African - Shear zone · Dom Feliciano Belt · Uruguay · Kinematic analysis

\section{Introduction}

Crustal-scale shear zones play a major role in the evolution of orogens. These shear zones can correspond to continental transform faults, such as the San Andreas Fault in California (Powell 1992), or the Alpine Fault in New Zealand (Moores and Twiss 1995, p. 144). They can be 
associated with escape tectonics in collisional orogens, like the North Anatolian Fault (Sengör et al. 2005), the Periadriatic Line (Schmid et al. 1989) or the Altyn Tagh fault system in northern Tibet (Wang 1997; Yin et al. 2002). Moreover, they can accommodate the strike-slip component of subduction in the upper plate, as is the case, for example, in the Southern Andes, the northern Cascades, and Sumatra (de Saint Blanquat et al. 1998).

The generation, ascent, and emplacement of granitic melts are often temporally and spatially related to shear zones (D'lemos et al. 1992; Hutton and Reavy 1992; Hutton and Siegesmund 2001). In addition, strike-slip basins associated with transform or transcurrent faults frequently form in transpressional orogens (Nilsen and Sylvester 1995). Furthermore, shear zones may constitute the boundaries between accreted terranes, and their study can provide insights into the history of accretion involved in the evolution of an orogen. The links between magmatism, sedimentary basins, and terrane accretion make the study of the kinematic evolution of major shear zones a key topic for reconstructing the history of orogens.

Transpressional deformation and the development of orogen-parallel shear zones characterize the Kaoko and Dom Feliciano Neoproterozoic belts of South America and Africa (Dürr and Dingeldey 1996; Goscombe and Gray 2008; Bitencourt and Nardi 2000). An orogen-parallel major shear zone system nearly $1,000 \mathrm{~km}$ long crosscuts the Dom Feliciano Belt (DFB) of southern Brazil and Uruguay. The Sierra Ballena Shear Zone (SBSZ) represents the system in Uruguay and the Dorsal de Canguçu (DCSZ) and Major Gercinho (MGSZ) defines the shear zone system in Brazil. The significance of this shear system is the subject of ongoing debate. Fernandes et al. (1993), Tommasi et al. (1994) and Fernandes and Koester (1999) interpreted this system as an intracontinental fault with associated syntectonic granitoids derived from both the crust and the mantle. Based on differences in Sm-Nd signatures, Basei et al. (2000, 2005) considered the shear zone system as a suture, with the fold and thrust belt representing a terrane accreted to the "Granite Belt". Despite this, Oyhantçabal et al. (2007) argued that most of the observed evolution for the southernmost part of the DFB corresponds to a post-collisional environment, where the transcurrent SBSZ played a major role in the ascent and emplacement of granitic plutons and in the evolution of associated basins. The question, if the SBSZ represents a former terrane boundary still remains open.

Although the shear zone system controls the architecture of the Belt and some structures are probably main geotectonic boundaries, detailed investigations are still scarce. This study presents structural, microstructural, kinematic, and preliminary geochronologic data from the SBSZ of the southernmost DFB (Figs. 1, 2). Temperature conditions during deformation were estimated and different deformation events are postulated for its evolution.

\section{Geological setting}

The DFB and the Río de la Plata Craton

The DFB is one of the orogens marginal to the Río de la Plata Craton resulting from the Neoproterozoic collision between the Río de la Plata, Congo and Kalahari cratons during the Brasiliano-Pan-African Cycle (780-450 Ma; Porada 1989). It extends for more than $1,200 \mathrm{~km}$ from southern Uruguay to the Santa Catarina State in Brazil.

The Sarandí del Yí Shear Zone (SYSZ) is located to the west of the DFB and divides the Río de la Plata Craton into two terranes (Fig. 1). The Paleoproterozoic Piedra Alta Terrane crops out west of this shear zone and is a cratonic domain not affected by Neoproterozoic events. The Nico Pérez Terrane (NPT), located between the SYSZ and the SBSZ, is a complex Archean to Proterozoic unit. The terrane is built up of several basement blocks comprising gneisses and granulitic rocks covered by metasedimentary platform successions and foreland basin deposits of the DFB (Basei et al. 2000; Hartmann et al. 2001). The basement units of this terrane were strongly reworked during Brasiliano events. To the north, in Río Grand do Sul (southernmost Brazil), the NPT is bound by the juvenile Neoproterozoic Sao Gabriel Block (Fig. 1). This block is composed by early Neoproterozoic volcano-sedimentary successions and orthogneisses (900-700 Ma) covered by late Neoproterozoic-Cambrian post-orogenic successions (Saalmann et al. 2006).

Schematically, three main geotectonic units are recognized in the DFB (Basei et al. 2000), from east to west: (1) Granite Belt, (2) Schist Belt, and (3) Foreland Belt (Fig. 1). The Granite Belt contains three granitic batholiths known as the Aiguá Batholith (Uruguay), Pelotas Batholith (Río Grande do Sul State, Brazil), and Florianópolis Batholith (Santa Catarina State, Brazil). High-K calc-alkaline signatures are preponderant, while subordinate peraluminous and alkaline metaluminous signatures are also present. Most of the intrusions are spatially and temporally related to the main shear zones (Bitencourt and Nardi 2000; Oyhantçabal et al. 2007). The Schist Belt is a fold and thrust belt comprising pre-collisional Neoproterozoic metavolcanic and sedimentary sequences. Greenschist to lower amphibolite facies conditions prevailed in these sequences. The Lavalleja Group of Uruguay, the equivalent Porongos (Rio Grande do Sul) and the Brusque (Santa Catarina) Groups of southern Brazil make up the different lithostratigraphic units defined by the Schist Belt (Basei et al. 2008). The Foreland Belt consists of several volcano-sedimentary and 


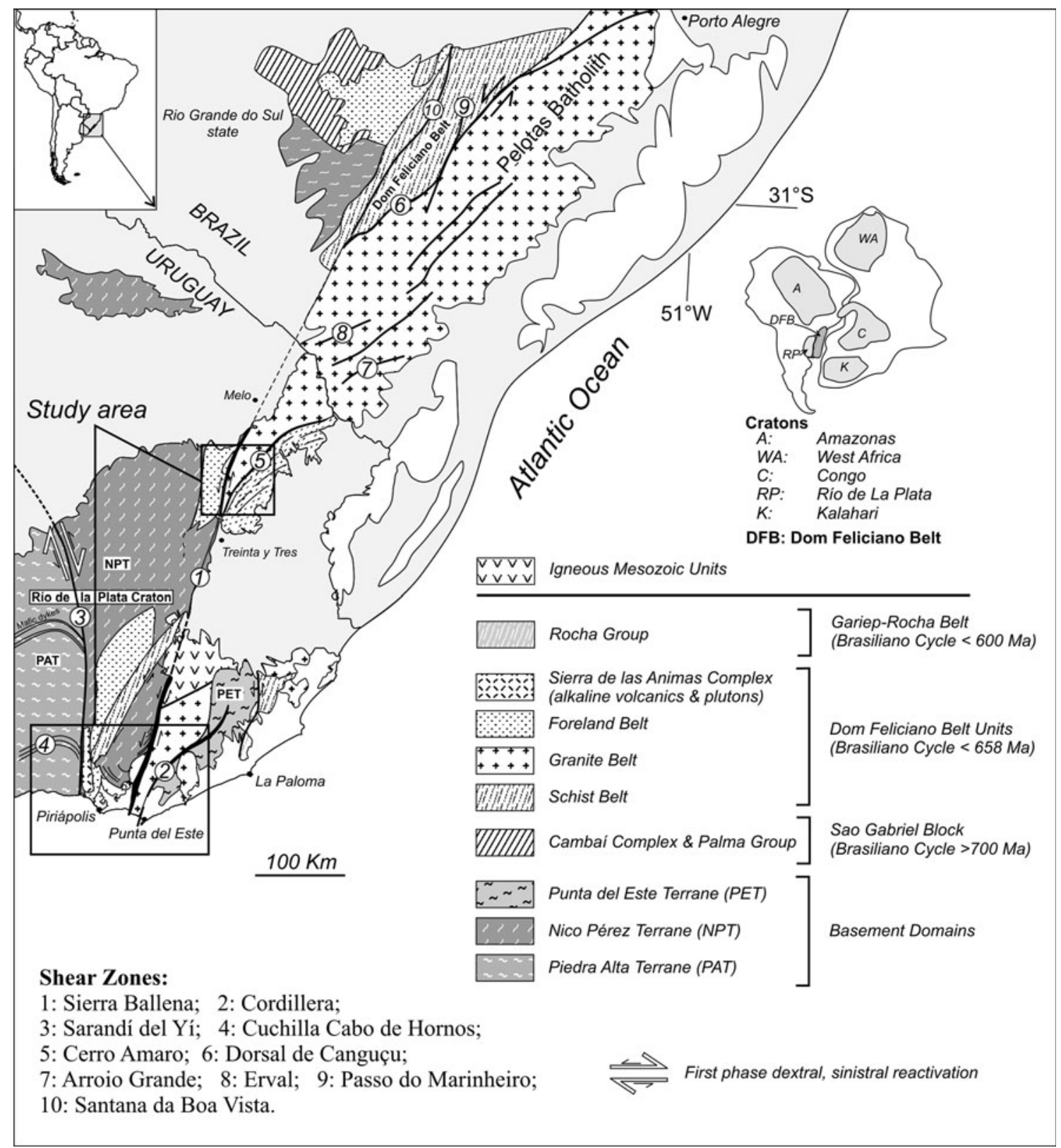

Fig. 1 Regional geological map of the southern Dom Feliciano Belt showing the major shear zones, based on data from Basei et al. (2000, 2005), Hartmann et al. (2001, 2002), da Silva et al. (2005), Philipp and Machado (2005) and Oyhantçabal et al. (2007)

sedimentary successions associated with the post-collisional evolution of the belt.

In the study area (Fig. 2), the basement of the NPT comprises the gneissic Campanero Unit $(1.7 \mathrm{Ga}$; Mallmann et al. 2003) and tectonic slivers of a platform succession (Zanja del Tigre Formation; Sánchez-Bettucci and Ramos 1999; Sánchez-Bettucci et al. 2001). According to Basei et al. (2006), Mesoproterozoic detrital zircons constrain the maximum age for the Zanja del Tigre Formation. The Foreland Belt is represented by marine to molassic deposits of the Arroyo del Soldado and Maldonado Groups
(Gaucher 2000; Gaucher et al. 2003, 2004; Pecoits et al. 2004; Teixeira et al. 2004; Pecoits et al. 2008).

The Punta del Este Terrane (PET; Preciozzi et al. 1999) comprises the pre-Brasiliano basement located east of the SBSZ (Fig. 1). Basement rocks consist of orthogneisses, paragneisses, amphibolites, and migmatites (Masquelin 2004) of the Cerro Olivo Complex (Fig. 2). Age relations of the PET are not well constrained. Preciozzi et al. (1999) reported Mesoproterozoic conventional U-Pb ages $(1,100-$ $900 \mathrm{Ma})$ for this terrane, which suggests that it could represent a portion of the Namaqua Metamorphic Complex 
Fig. 2 Geological map of the study area showing the main geological units (simplified after Oyhantçabal 2005). SYSZ

Sarandí del Yí Shear Zone, SBSZ Sierra Ballena Shear Zone, CSZ Cordillera Shear Zone. See location on Fig. 1

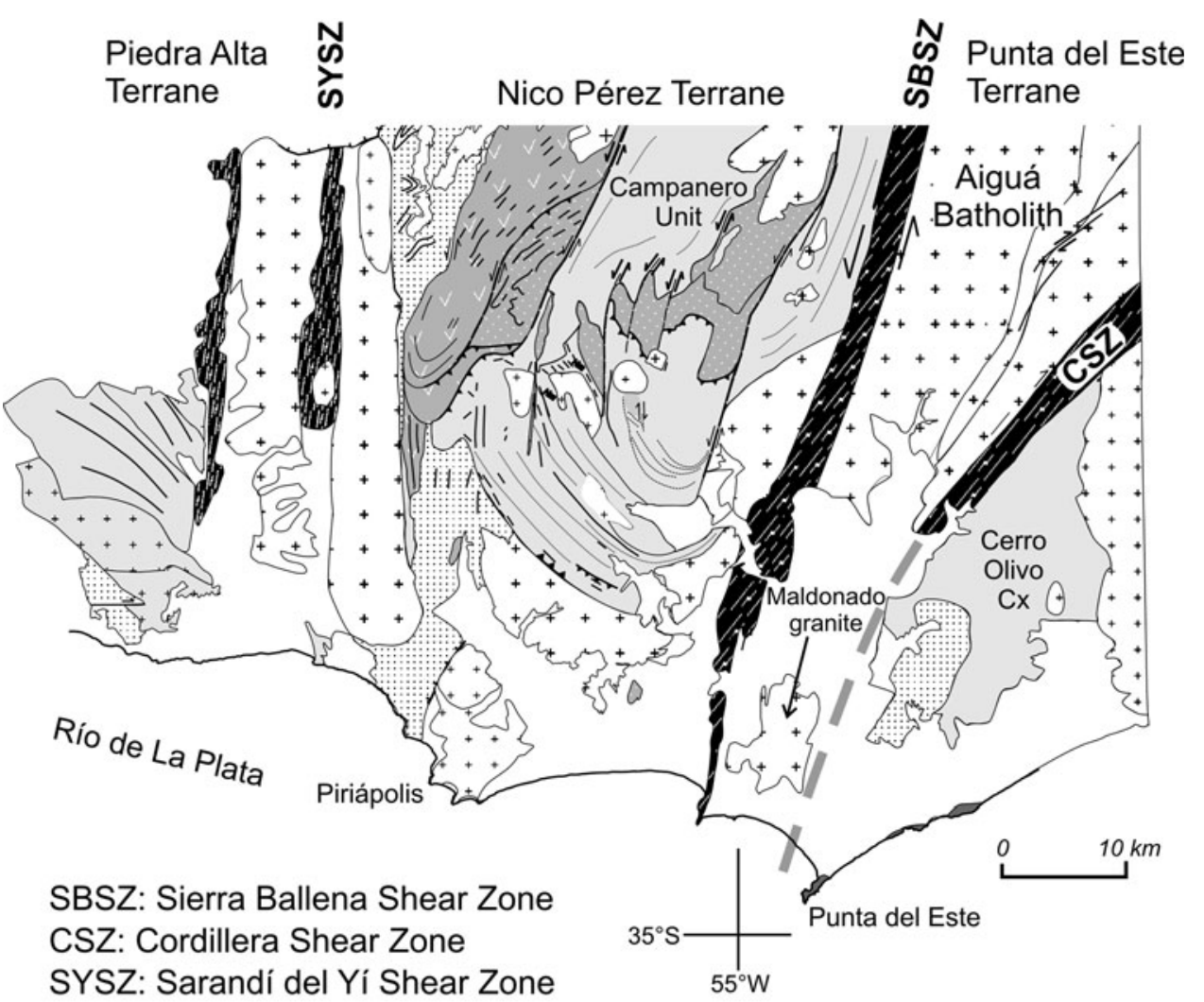

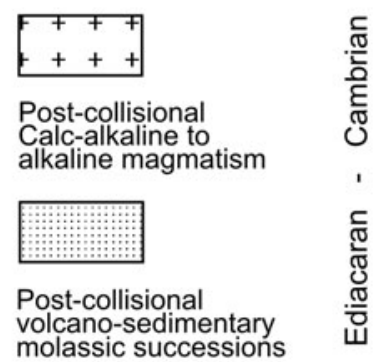

Pre-collisional Zanja del Tigre Formation

Pre-Brasiliano Basement

Meso and

Paleoproterozoic

Neoproterozoic molassic successions

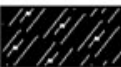

Mylonites in the Shear Zones of southern Africa (Basei et al. 2005). Hartmann et al. (2002) interpreted inherited 2.05 Ga (U-Pb SHRIMP) zircon cores in a Neoproterozoic orthogneiss from this terrane as evidence of a Paleoproterozoic basement. However, during the late Neoproterozoic, the PET was also strongly reworked. As indicated by Bossi and Gaucher (2004), the DFB seems to be a collage of diachronous units of various provenances and amalgamated at different stages (Leite et al. 1998). The scarcity of isotopic data, especially in Uruguay, determined that contrasting geotectonic models have been proposed (Bossi and Gaucher 2004; Basei et al. 2005; Basei et al. 2008).
High-T tectonites of the basement on both sides of the southernmost SBSZ

The basement situated in the eastern (Masquelin 2004) and western (Oyhantçabal 2005) domains of the SBSZ consists mainly of mylonitic gneisses (Fig. 3). Frequent textural features of these gneisses include sub-equant feldspar grains with straight boundaries and triple junctions at nearly $120^{\circ}$, chessboard patterns in quartz (Fig. 4a, evidence for prismatic and basal subgrain boundaries; Kruhl 1996) and lobate grain boundaries between quartz and feldspar. Quartz ribbons (aspect ratio 3-5:1), where 


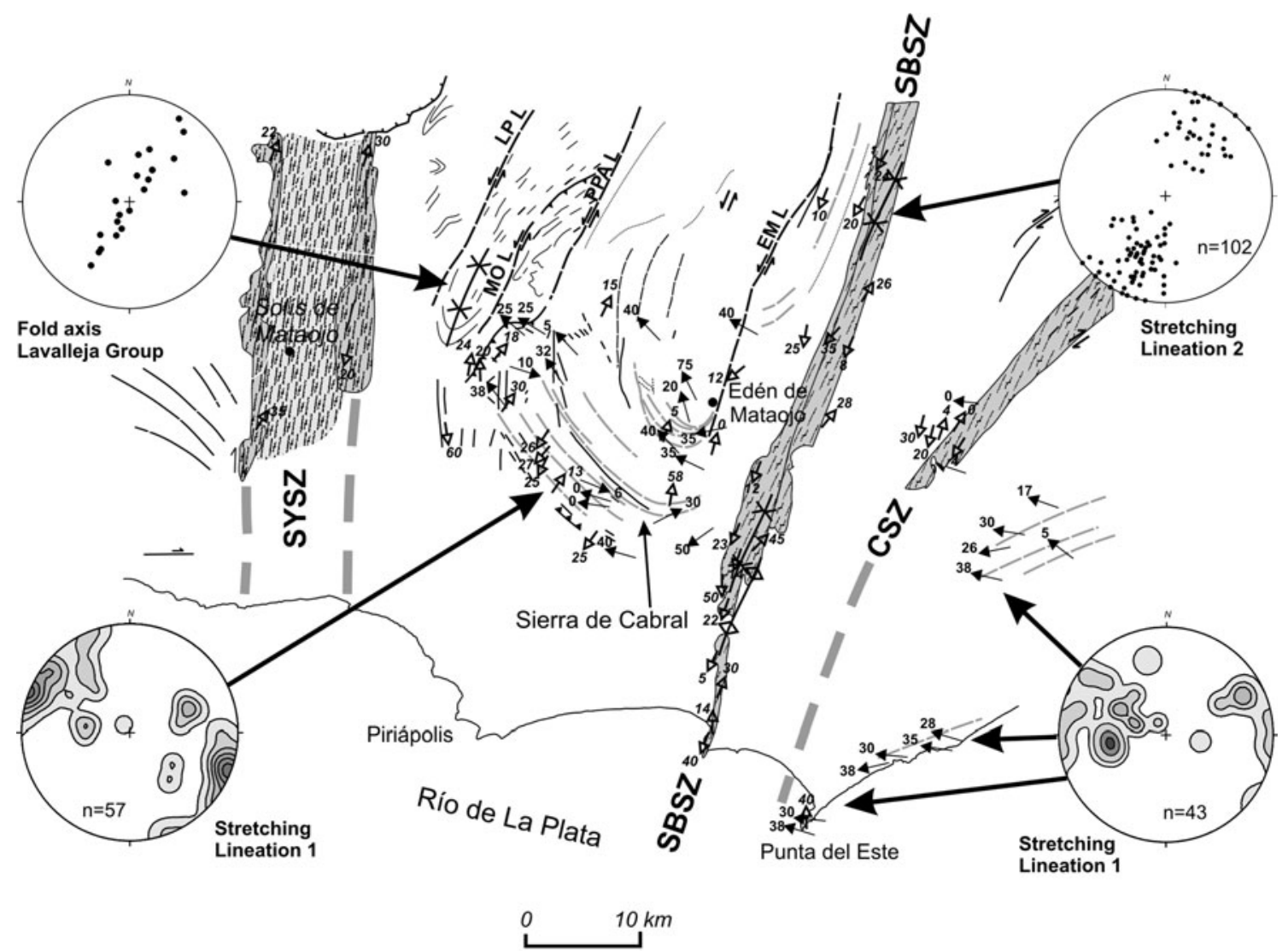

Lineaments:

LPL: La Plata

MOL: Mina oriental

PPAL: Puntas del Pan de Azúcar

EML: Edén de Mataojo

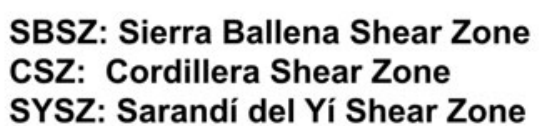

Stretching
lineations
${ }^{35} L_{1}$
in low-grade supracrustals

Fig. 3 Structural map of the study area showing the main structural elements (simplified after Oyhantçabal 2005). Stereograms: equal area, lower hemisphere. Contours: 1, 3, 5... times uniform distribution. See location on Fig. 1

present, are monocrystalline to polycrystalline containing rectangular or irregular crystals (types 3 and 4 of Boullier and Bouchez 1978). At higher strain levels, the phase boundaries between elongated quartz grains and feldsparrich domains show cusps in the direction of the foliation (Fig. 4b) similar to those described by Gower and Simpson (1992). These microstructures suggest grain boundary migration, grain growth, and fluid-assisted grain boundary diffusion during high-T deformation. Rotation recrystallization subgrains and deformation lamellae, frequently observed in quartz, indicate overprinting by younger lower$\mathrm{T}$ deformation events.
Evidence of partial melting is observable in some of the gneisses, as indicated by interstitial micropegmatitic intergrowths of quartz and feldspar. Such partial melting can enhance deformation by diffusional creep (Dell'Angelo et al. 1987). Garlick and Gromet (2004) described similar microstructures attributed to diffusional creep associated with partial melting in the high-T mylonites of New England (USA).

In highly deformed rocks, complete segregation of quartz and feldspar is attained and "striped gneisses" are formed. In these "striped gneisses", straight ribbons up to several centimeters long (axial ratio >10: 1) separate 

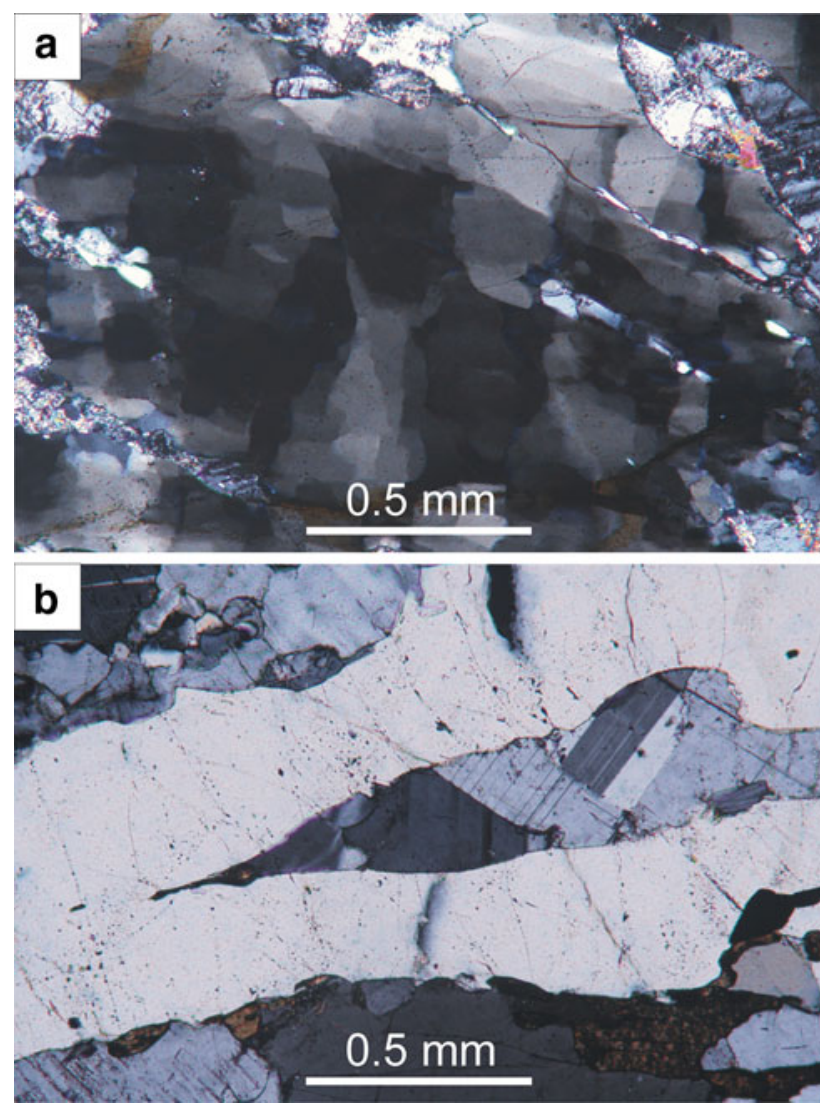

Fig. 4 Microstructural features of the high-T tectonites: a quartz with chessboard extinction pattern indicating simultaneous basal and prismatic slip, b quartz-feldspar grain boundary cusps parallel to foliation, indicating diffusional creep

feldspar-rich domains with evidence of high-T recrystallization. According to Hippert et al. (2001), this kind of microstructure relates to plastic deformation and coalescence of scattered quartz grains associated with enhanced grain boundary mobility in a high-grade metamorphic environment.

On both sides of the SBSZ, the high-T foliation is associated with stretching lineations $\left(\mathrm{L}_{1}\right)$ inclined approximately $30^{\circ}$ toward the NW or SE (see stereograms in Fig. 3) and thrusts vergent toward the S-SW (Campal and Schipilov 1999; Masquelin 2004). The symmetry of boudinage and the lack of other asymmetric structures suggest that this event was dominated by pure shear. Lineation $\mathrm{L}_{1}$ is folded, together with the high-T foliation, by folds with axes near parallel to the SBSZ and to lineation $\mathrm{L}_{2}$, probably due to strain partitioning into contraction and wrenchdominated domains. Small sinistral shear zones, trending $020^{\circ}$, parallel to the SBSZ, frequently rework the high-T foliation of the basement and the Zanja del Tigre formation. This is consistent with mentioned microstructural evidences of low- $\mathrm{T}$ overprinting of the high- $\mathrm{T}$ microstructures.
The temperature conditions $\left(650-750^{\circ} \mathrm{C}\right)$ of the deformation on the western side of the SBSZ are constrained by the paragenesis quartz + muscovite and the presence of chessboard patterns in quartz (Kruhl 1996). The regional association with migmatites containing sillimanite in the paleosome is consistent with regional high temperature conditions. On the eastern side of the SBSZ, the occurrence of hypersthene in the high-T mylonites indicates granulite facies metamorphic conditions. Masquelin et al. (2001, 2002) bracketed the conditions during this high-grade metamorphism into two deformation-metamorphism events. The first event (M1) shows temperatures ranging between 770 and $850^{\circ} \mathrm{C}$ and pressures between 7 and $11 \mathrm{kbar}$, and the second event (M2) temperature of ca. $850^{\circ} \mathrm{C}$ and lower pressures $(2-5 \mathrm{kbar})$. These data indicate near-isothermal decompression.

\section{Macrostructure of the Sierra Ballena and associated shear zones}

The SBSZ is part of a major shear system, composed of approximately north-south and southwest-northeast trending branches. The location and orientation of various shear zones, including data from Fernandes and Koester (1999), Ramgrab (1999), Porcher (2000), Philipp and Machado (2005), da Silva et al. (2005) and Oyhantçabal (2005), for this shear system of the DFB in Rio Grande do Sul and Uruguay is schematically summarized in Fig. 1. The PaleoMesozoic Paraná Basin covers the area between the Dorsal de Canguçu and Major Gercinho shear zones, making correlation difficult and not the topic of the current paper.

The Cerro Amaro shear zone of northern Uruguay (Fig. 1) has an observed maximum width of $10 \mathrm{~km}$ and is composed of mylonites, ultramylonites, and phyllonites derived from granitic protoliths. The foliation is sub-vertical and strikes $045^{\circ}$ to $090^{\circ}$, while stretching lineations are sub-horizontal and plunging to the west-southwest. These structural data are consistent with transcurrent shear, but the sense of shear remains unclear. The southwestern extreme is reworked by the SBSZ, while to the northeast the Arroio Grande Shear Zone of Rio Grande do Sul (Philipp and Machado 2005) may represent the prolongation. Ultramafic rocks altered to tremolite and serpentine (Bossi and Navarro 1988), which occur as slivers in the mylonites, together with the width of this shear zone, suggest that it could correspond to a main geotectonic boundary.

Three main tectonic lineaments characterize the southernmost DFB in Uruguay (Fig. 1). The Sarandí del Yí, Sierra Ballena and Cordillera shear zones make the boundaries of the main domains and control the architecture of the study area. Schematic maps in Figs. 1, 2, 3 depict the main structural features at the macro scale. 
The SBSZ is a major near straight lineament, trending ca. $020^{\circ}$ from southern to northern Uruguay, where the outcrops are covered by Paleozoic sediments. The shear zone's width is about $4 \mathrm{~km}$. Several curved branches of shear zones (e.g. Cordillera and Cerro Amaro shear zones, see Fig. 1) oriented with an average of $040^{\circ}$ to $080^{\circ}$ are also observed.

Based on geomorphology and lithologies, three main different sectors are recognized in the SBSZ: the southern (Fig. 2), the central, and the northern sector. A strong geomorphologic contrast between the mylonites of the shear zone and the country rocks distinguishes the northern and southern sectors. The presence of quartz mylonites and mylonitic porphyries forming ridges more resistant to weathering creates this high contrast. In the central sector, the predominance of granitic mylonites together with the low relief associated with subsidence related to a Mesozoic Basin, results in a correspondingly weak geomorphological expression.

Deflection of the pre-existing structure of the basement (Fig. 3) documents the sinistral shear sense of the SBSZ. The regional structure is clearly observable in satellite images of the areas surrounding the towns of Edén de Mataojo and Aiguá on the western side of the SBSZ. The sinistral Edén the Mataojo Lineament (Oyhantçabal 2005; Harries et al. 2007), roughly $4 \mathrm{~km}$ west of the SBSZ and trending NNE-SSW, separates the highly deformed rocks related to the SBSZ from less deformed lithologies. Northsouth transposed basement crops out between the Edén de Mataojo Lineament and the SBSZ. To the west of the Edén de Mataojo Lineament, the contacts between the basement and the supracrustal sequences have been sinistrally displaced by left-lateral faults and shear zones parallel to the SBSZ (Figs. 1, 2).

The Cordillera Shear Zone (Figs. 1, 2) shows evidence of a dextral sense of shear, and is probably a conjugate fault to the SBSZ. The influence of the SBSZ produces a sigmoidal shape ( $\mathrm{S}-\mathrm{C}$ like geometry) in the Cordillera Shear Zone (Fig. 1). A similar geometrical feature is observable west of the SBSZ, at a range of scales, for example between the SBSZ and the Puntas del Pan de Azúcar Lineament and between the Puntas del Pan de Azúcar and Mina Oriental Lineaments (Fig. 3).

A main feature of the area is the role played by the macrostructures in the emplacement of granitic plutons. Preferential intrusion of granites between the Sierra Ballena and Cordillera Shear Zones forming the Aiguá Batholith is visible on the geological map in Figs. 1, 2. The confluence of both shear zones could be a major factor controlling magma ascent and creating the space for the emplacement of large volumes of granitic magma.

\section{Mesoscopic structure of the SBSZ}

Foliations and lineations

Low- to medium-T mylonitic foliation is characteristic of the Sierra Ballena and Cordillera shear zones, as well as several minor strike-slip shear zones with the same kinematics. The mean attitude of the mylonitic foliation is $030^{\circ} / 85^{\circ} \mathrm{SW}$. A difference of ca. $10^{\circ}$ is observable between the regional strike of the shear zone $\left(020^{\circ}\right)$ and the mean strike of the foliation, which is consistent with sinistral kinematics. Rotation of the regional foliation adjacent to the shear zone indicates a minimum of $30 \mathrm{~km}$ of sinistral displacement.

The stretching lineation is normally sub-horizontal $\left(\mathrm{L}_{2}\right.$; Fig. 3) with a density maximum of $12^{\circ} / 208^{\circ}$, indicating the possibility of an eastside up component of movement on the SBSZ (Harries et al. 2007). Microboudinage of tourmaline crystals in the quartz mylonites and of feldspar in the granitic mylonites prove that it is in fact a stretching lineation. Steeply plunging lineations are also observable, for instance in the syntectonic Maldonado Granite of the Aiguá Batholith, where oblate enclaves indicate intense flattening during transition from magmatic to solid-state flow (Oyhantçabal et al. 2007).

\section{Folds}

Folding of the mylonitic foliation is an outstanding feature of the SBSZ. The folds are normally tight and upright with sub-horizontal hinges and show evidence of flattening (Fig. 5a, f). An en-echelon arrangement along the shear zone at the regional-scale is observable and is consistent with the sinistral shear sense. A schematic cross-section of the shear zone showing the folded quartz mylonites and mylonitic porphyries is shown in Fig. 6.

Different fold geometry and different relationships between folds and stretching lineations are observed. At least three main kinds of folds are present. F1 folds are isoclinal or tight, show hinges parallel to the stretching lineation and evidence of flattened limbs. The F2 folds are also tight to isoclinal but show folded stretching lineations. A symmetrical U-pattern (type 4 of Ghosh and Chatterjee $1985)$ is sometimes observed in the folded lineations of F2 folds (Fig. 5b). F3 folds are open to close, strongly asymmetric and the hinge is perpendicular to the stretching lineation. Despite different rheological behavior influence fold geometry, observed features indicate folds formed at different stages of the shear zone evolution: earlier folds show hinges parallel to the lineation, while later folds show folded lineations.

Curvilinear hinges typical of sheath folds are seldom. The high ductility contrast between the dikes (mylonitic 
Fig. 5 a Fold of the mylonitic foliation in granitic mylonite, which show evidence of flattening. Looking S. b Symmetric U-pattern of folded lineation. Looking W. Coin (1 $\mathrm{cm}$ in diameter) for scale. c Asymmetric folds indicating sinistral sense of shearing. Looking down, top to W. Coin $(1 \mathrm{~cm}$ in diameter $)$ for scale. d Dike of mylonitic porphyry $(D)$ intruding granitic mylonites. Looking down, top to $\mathrm{S}$. Hammer (33 $\mathrm{cm}$ long) for scale. e Quartz mylonite showing boudinage (arrow) perpendicular to stretching lineation $(L)$. Looking S. Pen (12 cm long) for scale. f Cylindrical fold; detail of flattened shape. Looking

$\mathrm{S}$. Coin $(1 \mathrm{~cm}$ in diameter) for scale
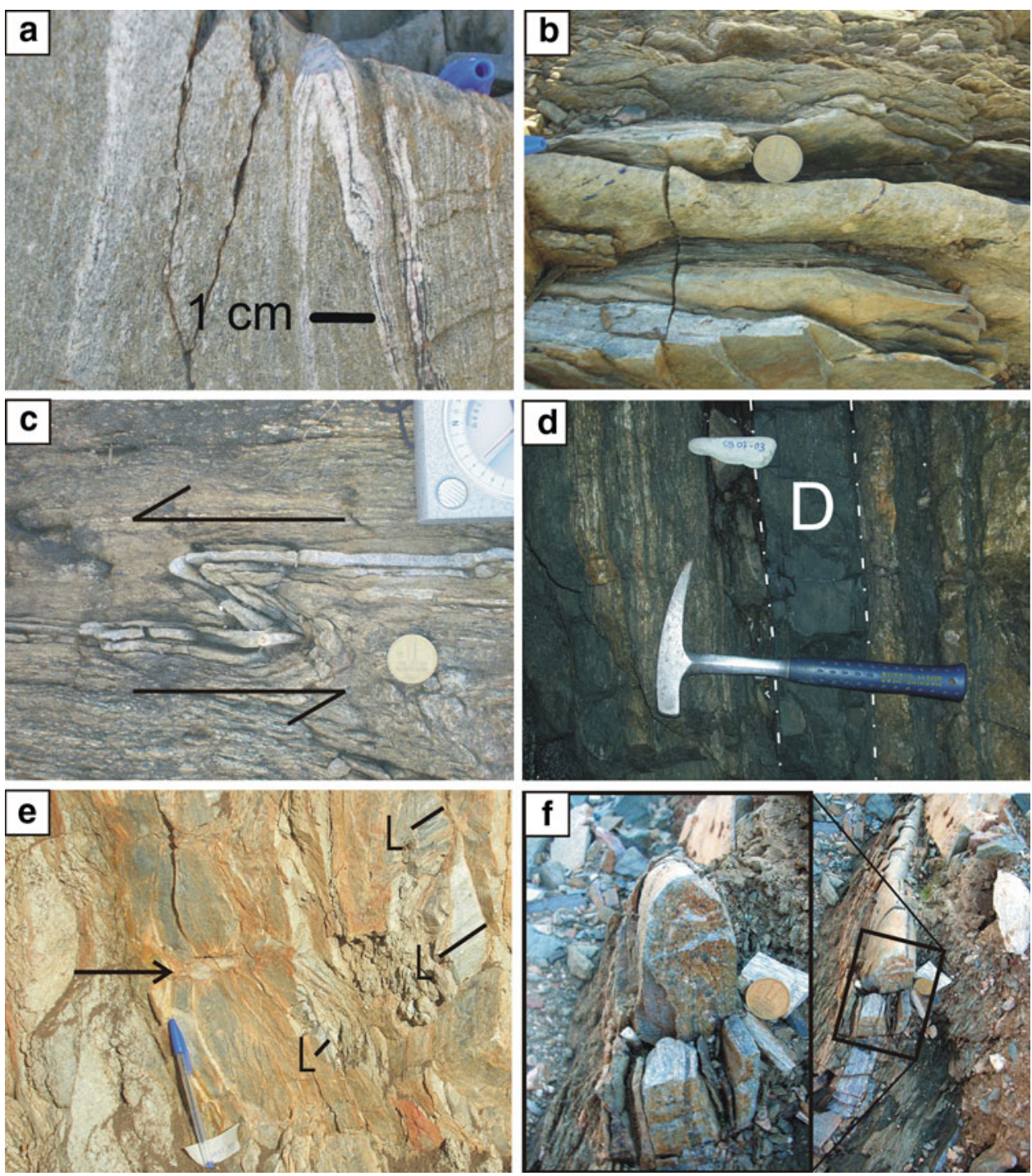

Fig. 6 Idealized profile of the Sierra Ballena Shear Zone showing the relation between the different mylonitic rocks
W

$E$

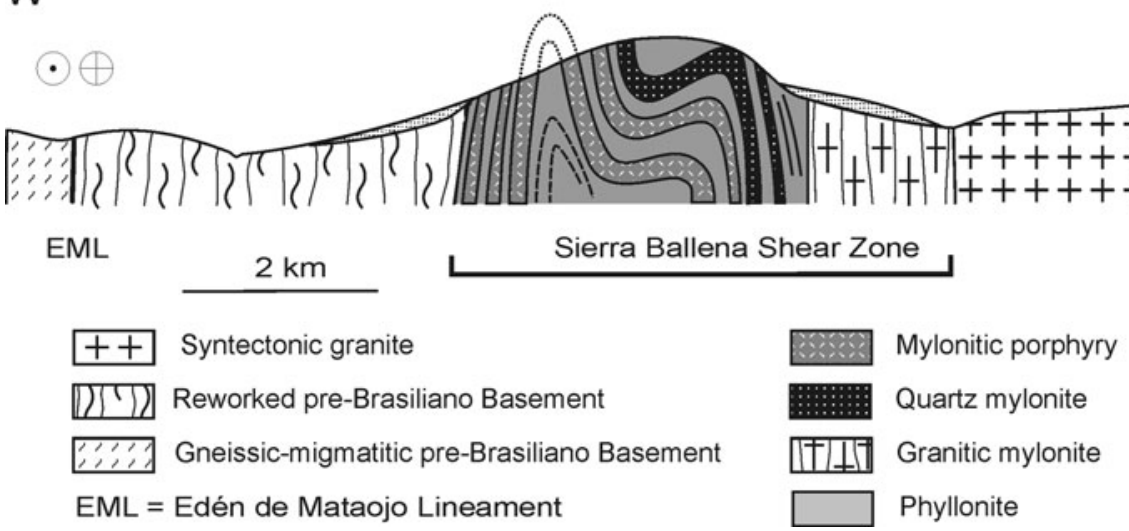

porphyries and quartz mylonites) and adjacent phyllonites probably concentrated the simple shear deformation in the latter, preserving the shape of the folds in the dikes.
Nevertheless, near cylindrical fold shapes are also visible in less competent lithologies, suggesting that the component of simple shear in the deformation was low (Fig. 5f). 
The symmetric U-pattern of folded lineations also indicates a large pure to simple shear ratio (Sengupta and Ghosh 2004).

The last generation of folds with the hinge perpendicular to the lineation is strongly asymmetric (Fig. 5c), and although folds are not generally a reliable shear indicator (Passchier and Trouw 1996), the asymmetry is consistent with a sinistral sense.

\section{Kinematic indicators}

Sinistral S-C structures are a frequent feature in the deformed rocks of the area. In the syntectonic granites (e.g. some outcrops of the Maldonado granite), the $\mathrm{C}$ surface is oriented $000^{\circ}-020^{\circ}$ and intersects an $\mathrm{S}$ surface marked by the shape-preferred orientation of feldspar megacrysts oriented at $030^{\circ}-045^{\circ}$. Porphyroclasts in the granitic mylonites of the SBSZ show tails with $\sigma$ - and $\delta$-shape and normally indicate a sinistral shearing sense. In the phyllonites, where porphyroclasts are small and rounded, the sense of shearing can only be established at the microscopic scale.

\section{Petrography and microstructural features of the mylonitic rocks of the SBSZ}

Four different types of mylonites are identifiable in the SBSZ: granitic mylonites, phyllonites, quartz mylonites, and mylonitic porphyries.

\section{Granitic mylonites}

These mylonites are the most widespread lithological type and display a strong foliated matrix wrapping around alkali feldspar and plagioclase porphyroclasts. Gradual transitions from protomylonite and mylonite to ultramylonite are observed. The feldspar porphyroclasts are usually rounded and the predominant geometry is $\sigma$-type indicating a sinistral sense of shear and suggesting low vorticity. Alkali feldspar porphyroclasts are usually pink and range from $5 \mathrm{~mm}$ to $5 \mathrm{~cm}$, while plagioclase porphyroclasts are white and $3-10 \mathrm{~mm}$ in size. The porphyroclasts show core and mantle structures, bent twins, and subgrains. They are frequently fractured and the necks are filled with quartz. Quartz grains show undulatory extinction with development of small subgrains and recrystallized grains. Elongate grains and short to very stretched quartz ribbons wrap around fragments of feldspar (Fig. 7a, b).

Dislocation creep is the main deformation mechanism for quartz, which led to subgrain rotation recrystallization (dislocation regime 2 of Hirth and Tullis 1992). The main ferromagnesian mineral is biotite. Accessory minerals include allanite and epidote, often in trains, with sphene occurring as euhedral crystals wrapped around by the mylonitic foliation. Pegmatitic dikes, interpreted as synmagmatic to the protolith, are frequent in these granitic mylonites and are also folded and strongly deformed. The microstructures observed in feldspar and quartz are typical of deformation in upper greenschist to lower amphibolite facies metamorphic conditions (Passchier and Trouw 1996; Tullis et al. 2000). In some syntectomic granitic intrusions, a transition from magmatic to solid-state microstructures is preserved (e.g. in the Maldonado granite, Oyhantçabal et al. 2007) indicating deformation during later cooling does not completely overprint the higher $\mathrm{T}$ microstructures.

\section{Phyllonites}

The phyllonites are very fine-grained and finely banded. On a microscopic scale, they show small rounded porphyroclasts of feldspar $(0.3-0.7 \mathrm{~mm})$ in a very finegrained and layered matrix $(0.2-0.5 \mathrm{~mm}$ thick layers), rich in white mica and tiny biotite laths (Fig. 7c). The distribution of the micas around the porphyroclasts is asymmetric, indicating a sinistral shear sense. An extensional crenulation cleavage (Platt and Vissers 1980) or "C" band cleavage (Berthé et al. 1979) with obliquely oriented phyllosilicates is also present at a low angle to the layering and probably accommodated a large amount of extension parallel to the stretching lineation. Feldspar porphyroclasts display little intracrystalline deformation. The very weak matrix apparently accommodates most of the strain. Muscovite mica fish (ca. $0.2 \mathrm{~mm}$ ) show a sinistral sense of shear. When fine quartz layers are present, recrystallized grains are elongated with the long axis oblique on the quartz layer corroborating the sinistral kinematics. Epidote is abundant, occurs in trains parallel to the mylonitic foliation, and is related to the breakdown of plagioclase. Tourmaline, carbonate, and relicts of sphene are frequent accessory minerals. The observed microstructures and mineral assemblages are consistent with sinistral shearing during mid greenschist facies conditions.

Gradual transitions from granitic mylonite to phyllonite are well exposed in the SBSZ and demonstrate that these phyllonites developed from a granitic protolith and do not represent slices of metasediments in the granitic mylonite. Studies in other large shear zones (Imber et al. 1997 and references therein) indicate that under mid-crustal conditions phyllonites can derive from a granitic protolith through comminution of feldspar and retrograde alteration to phyllosilicates such as muscovite due to the influx of fluids. Jefferies et al. (2006) emphasized the importance of these weak zones for the evolution and reactivation of the shear zones. Hemley and Jones (1964) quoted in Wibberley and McCaig (2000) indicate the following reactions are 
Fig. 7 Microstructural features of the mylonites of the SBSZ. Sections cut perpendicular to foliation and parallel to lineation: a Granitic mylonite: elongated quartz show undulose extinction and development of subgrains by subgrain rotation in dislocation creep regime 2. Brittle deformation in feldspar. b Fractured feldspar and ribbons of fine-grained recrystallized quartz deformed by regime 2 dislocation creep. c Phyllonite: rounded porphyroclasts of feldspar in mica-rich matrix. d Quartz mylonite: SC structure; muscovite in $\mathrm{C}$ planes. e Mylonitic porphyry with euhedral feldspar porphyroclast (residual phenocryst), in foliated matrix. f Magmatic embayment in partly recrystallized quartz porphyroclast (residual phenocryst). All photomicrographs under crossed polarized light
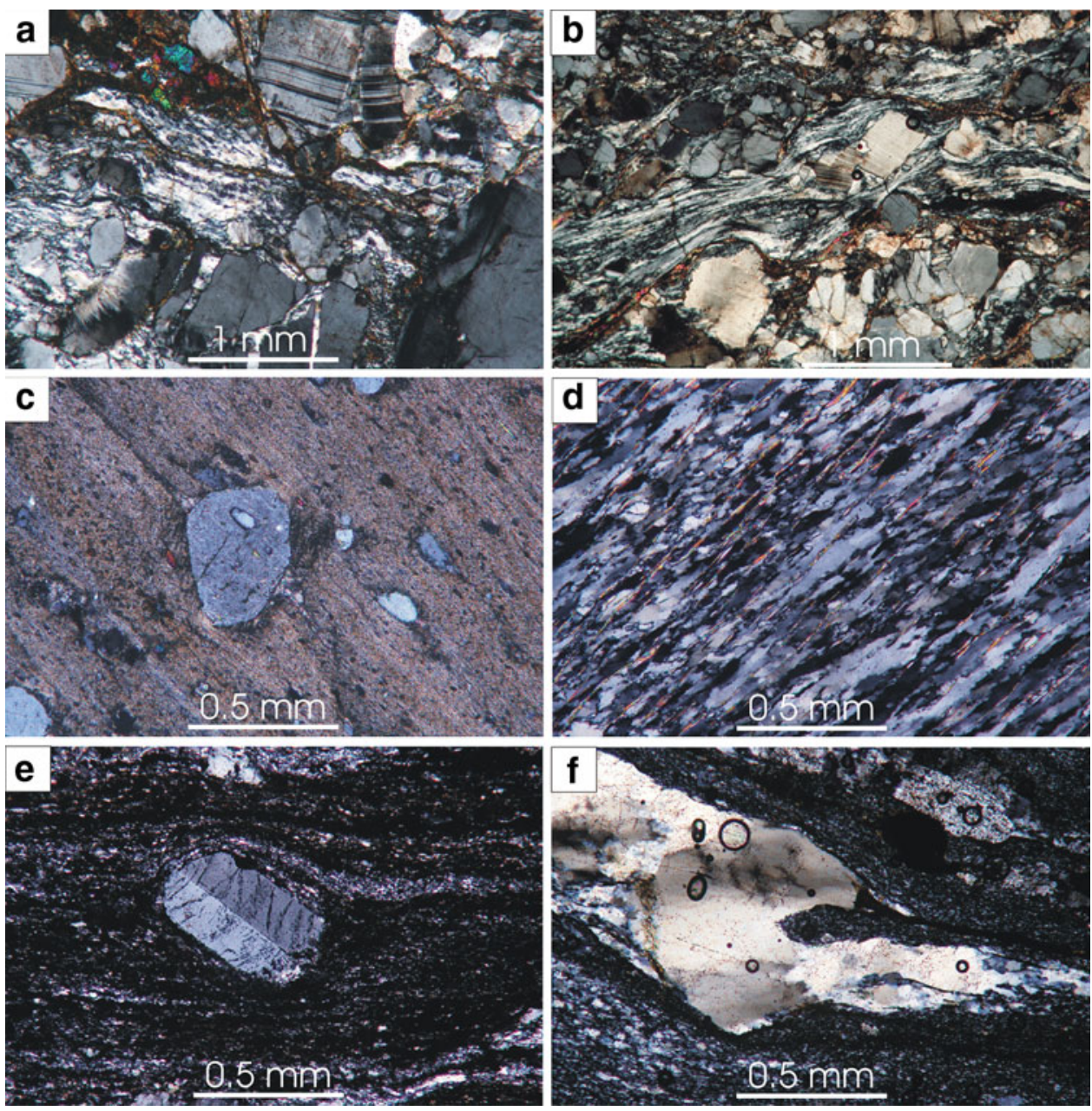

possibly involved in the breakdown of feldspar to muscovite, which require acidic fluids:

$$
\begin{aligned}
& 3 \mathrm{NaAlSi}_{3} \mathrm{O}_{8}+\mathrm{K}^{+}+2 \mathrm{H}^{+} \rightleftarrows \\
& \mathrm{KAl}_{3} \mathrm{Si}_{3} \mathrm{O}_{10}(\mathrm{OH})_{2}+6 \mathrm{SiO}_{2}+3 \mathrm{Na}^{+} \\
& 3 \mathrm{KAlSi}_{3} \mathrm{O}_{8}+2 \mathrm{H}^{+} \leftrightarrows \\
& \mathrm{KAl}_{3} \mathrm{Si}_{3} \mathrm{O}_{10}(\mathrm{OH})_{2}+6 \mathrm{SiO}_{2}+3 \mathrm{~K}^{+}
\end{aligned}
$$

Considering the close spatial association of phyllonites and quartz mylonites and the lack of quartzites in the country rock of the shear zone, this alteration of feldspar to mica is considered a probable source of silica for the quartz veins that later evolved to quartz mylonites.

\section{Quartz mylonites}

The quartz mylonites are composed mainly of quartz with accessory sericite, tourmaline, zircon, and opaques. Dynamic recrystallization of quartz results in new elongated quartz grains (ca. $0.2 \times 0.04 \mathrm{~mm}$ ) at higher angle to foliation ( $\mathrm{S}-\mathrm{C}$ like structure), indicating sinistral shearing. Sericite is concentrated in these discrete $\mathrm{C}$ surfaces
(Fig. 7d). Boudinage of tiny tourmaline crystals wrapped around by the foliation indicate the stretching direction.

Recrystallization observed in quartz includes subgrain rotation recrystallization, and grain boundary migration. As a result of the grain boundary migration, grains are consistently coarser in mica-poor layers and micas are sometimes included in quartz grains. When these quartz veins are folded, the foliation outlined by the orientation of quartz grains $\left(\mathrm{Smyl}_{n}\right)$ is also folded, and an axial plane foliation $\left(\operatorname{Smyl}_{n+1}\right)$ is observable.

The observed microstructures are similar to those described by Hirth et al. (1998) in sheets 3 through 6 of the Heavitree quartzite (Alice Springs Orogen, Central Australia). This denotes that recovery and recrystallization occurred by subgrain rotation and grain boundary migration (transition from regime 2 to regime 3 of Hirth and Tullis 1992) under upper greenschist to lower amphibolite facies metamorphic conditions. The observed grain boundary migration suggests amphibolite facies conditions were attained. Despite this, the mentioned folding of the foliation with occasional development of an axial plane foliation with fine-grained sericite indicates reworking 
under greenschist facies metamorphic conditions. This kind of evolution of deformation from higher to lower temperature conditions has been described in the Dorsal de Canguçu shear zone (Tommasi et al. 1994).

It is suggested that these quartz mylonites developed from quartz veins emplaced in the SBSZ. The breakdown of feldspar to mica associated with the formation of the phyllonites is proposed as the source of the silica for these veins.

\section{Mylonitic porphyries}

Mylonitic porphyries are one of the most outstanding features of the SBSZ. They are highly resistant to weathering and form very elongated hills (Sierra Ballena and Sierra de los Caracoles in the southern part of Uruguay and Cerro Largo in the north) contrasting geomorphologically with the surroundings. These rocks are black when not weathered, fine-grained, and occur as folded bodies up to $200 \mathrm{~m}$ thick, emplaced in granitic mylonites and phyllonites. The emplacement of these porphyries as dikes in granitic mylonite and phyllonite is clearly observable at the outcrop scale as narrow bodies (Fig. 5d), while thick ridges of mylonitic porphyry develop colluvium and their relation to the country rock is normally not exposed.

The texture is porphyritic with phenocrysts of quartz and euhedral alkali feldspar (about $0.5 \times 0.2 \mathrm{~mm}$ ) in a very fine-grained and banded matrix. Where the strain is low, the euhedral shape is well preserved (Fig. 7e) and embayments by magmatic corrosion are visible (Fig. 7f). As strain increases, fractured crystals, undulose extinction, and subgrain development is observable and the phenocrysts evolve to rounded porphyroclasts with $\sigma$ - and $\delta$ shapes. The $\delta$-shape is an indication of a component of simple shear, in view of the axial ratio $(n \sim 2)$ of the porphyroclasts (Passchier 1987). Quartz phenocrysts (about $0.5 \mathrm{~mm}$ ) are also common in some outcrops, usually transformed into elongated aggregates dynamically recrystallized and coarser-grained than the matrix. Mafic minerals are scarce. The most frequent is a Na-amphibole with blue to yellow pleochroism occurring as fine needles (about $0.02 \mathrm{~mm}$ in length). Occasionally, they are associated with aegirine-augite; the latter sometimes observed in pressure shadows of the feldspar phenocrysts.

The porphyritic texture and the fine-grained matrix of these dikes indicate subvolcanic emplacement. Evidence of dynamic recrystallization in feldspar, together with the occurrence of aegirine-augite in pressure shadows suggest that deformation of these mylonitic porphyries began in the magmatic stage and continued in the solid-state.

\section{${ }^{40} \mathrm{Ar} /{ }^{39} \mathrm{Ar}$ geochronology}

A ${ }^{40} \mathrm{Ar} /{ }^{39} \mathrm{Ar}$ study on muscovite, using the conventional technique, was performed to constrain the chronology of the tectonic events. Determinations were conducted at the University of Alabama Geochronology Laboratory. Details of the analytical technique are presented in the Appendix. The spectrum was considered to provide a plateau age if three or more consecutive gas fractions represent at least $50 \%$ of the total gas release and are within two standard deviations of each other (MSWD less than 2.5). The ${ }^{40} \mathrm{Ar} /{ }^{39} \mathrm{Ar}$ results are listed in Appendix Table 3, with all ages quoted to the $\pm 1 \sigma$ level and calculated using the constants of Steiger and Jaeger (1977). The integrated age is the age given by the total gas measured and is equivalent to a potassium-argon (K-Ar) age.

The first age determination of a mylonite from the SBSZ is presented in this study. Sample SB-6, a quartz mylonite, provided an appropriate concentrate of syntectonic muscovite. Two fractions were run and both yielded similar results; however, the second run, on a slightly larger grain, had an appropriate heating schedule that allowed for a more precise determination of the plateau age of $586 \pm 2 \mathrm{Ma}$ (Table 1; Fig. 8). This age is interpreted as a

Table $1{ }^{40} \mathrm{Ar} /{ }^{39} \mathrm{Ar}$ geochronology on syntectonic muscovite of the quartz mylonites

\begin{tabular}{|c|c|c|c|c|}
\hline Sample & Mineral & Integrated age (Ma) & Plateau age $(\mathrm{Ma})^{\mathrm{a}}$ & Plateau information \\
\hline SB-6 & Muscovite WM\#1 & $579.3 \pm 1.9$ & $581.4 \pm 5.3$ & $\begin{array}{l}9 \text { fractions } \\
98 \%{ }^{39} \mathrm{Ar} \text { release } \\
\text { MSWD }=7.7\end{array}$ \\
\hline SB-6 & Muscovite WM\#2 & $584.0 \pm 1.6$ & $585.8 \pm 1.6$ & $\begin{array}{l}11 \text { fractions } \\
96 \%{ }^{39} \mathrm{Ar} \text { release } \\
\mathrm{MSWD}=1.2\end{array}$ \\
\hline
\end{tabular}

Bold preferred age (ages reported at $1 \sigma$ )

${ }^{\text {a }}$ Plateau: $3+$ consecutive fractions, MSWD $<\sim 2.5$, more than $\sim 50 \%{ }^{39}$ Ar release. Plateau error is modified by the square root of MSWD (when MSWD is greater than 1.0) to more accurately reflect the scatter in the plateau. By this definition, only the second run of SB-6 Muscovite WM\#2 has a true plateau 


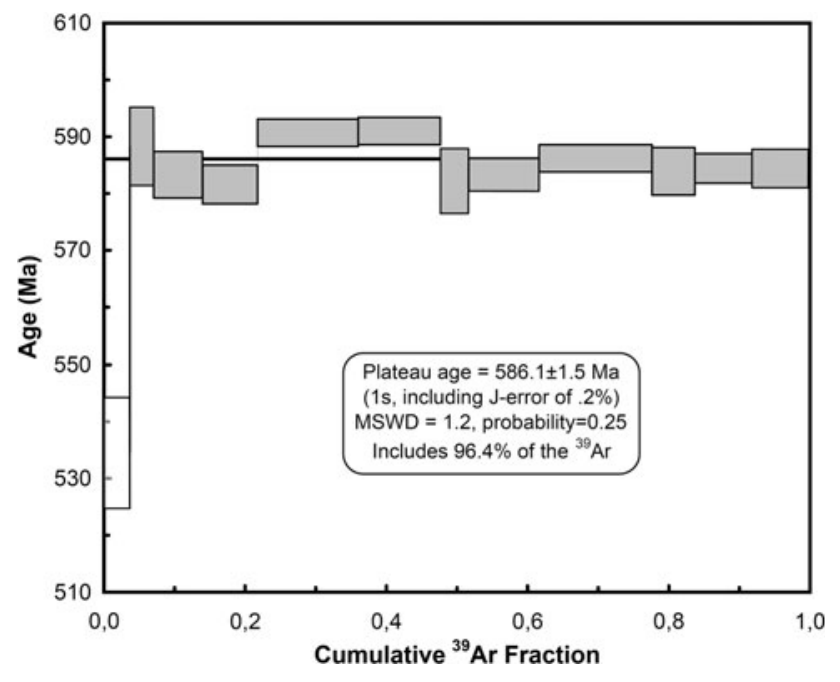

Fig. 8 Ar-Ar age spectrum for muscovite of sample SB-6. Box heights are $1 \sigma$, plateau steps are filled, rejected steps are open. Plateau: three or more consecutive fractions, MSWD $<\sim 2.5$, more than $\sim 50 \%{ }^{39}$ Ar release

cooling age due to the lower amphibolite to upper greenschist deformation conditions and represents therefore a minimum age for the deformation. The significance of this kind of ages is still discussed in regards to cooling, recrystallization, and/or neocrystallization (see discussion in Mulch and Cosca 2004).

\section{Discussion}

Macrostructure and tectonic regime

It is not possible, with the current state of information, to determine whether the high- $T$ tectonites observed in the country rock of the SBSZ are associated with an early stage of activity or they correspond to a deformation phase that preceded the transcurrent event of the shear zone. Harries et al. (2007) suggested that the occurrence of north-south reworked basement between the Edén de Mataojo Lineament and the SBSZ indicate that the latter nucleated as an early wide proto-shear zone while the foliation of the country rock rotated toward the shear plane during shearing. After an exhumation event, a later phase concentrated deformation in the core of the SBSZ producing strong rotation of the foliation and mylonitization. The Edén de Mataojo Lineament represents the youngest and more brittle event and suggests further exhumation.

On a regional scale, a key feature is that the SBSZ is associated with several diverging branches (Fig. 1). Two interpretations are possible for this shear zone pattern: (1) the shear zone branches represent synthetic horsetail splays; or (2) a first stage where conjugate dextral and sinistral shear zones were created was followed by sinistral shearing on near north-south shears. In the first case, the minor faults should also be sinistral and synthetic, while in the second the shear zones oriented near east-west should be dextral, although probably reactivated sinistrally at their bent terminations. Ramsay $(1980,1982)$ indicated that ductile shear zones normally occur in conjugate sets, that the obtuse angle faces the main shortening direction, and that generally one of them occurs later and displaces the older of the two. Hippert (1999) indicated that S-C fabrics at the thin-section, hand-specimen and outcrop scale, as well as conjugate fault/mylonite zones at a map scale, define a scale-invariant geometry over ten orders of magnitude. This relation seems to hold true as well for the Sierra Ballena and associated shear zones in Uruguay. Although kinematic investigations are still scarce in several shear zones associated with the SBSZ, the observed architecture together with available kinematic data indicating the presence of conjugate dextral and sinistral shear zones, favors the second model and explains the S-C-like geometry recognized on a regional scale. The style of the folds in the mylonitic foliation (tight to isoclinal with high cylindricity) with regional-scale en-echelon arrangement along the shear zone is consistent with sinistral pure sheardominated transpression. In the Taiwan Mountain Belt, a similar en-echelon arrangement of folds is visible where transpressional tectonics results from oblique convergence of crustal plates (Jeng et al. 2007). The symmetrical U-pattern of the folded stretching lineations, the oblate shape of the enclaves in syntectonic intrusions and boudinage structures showing extension in the $\mathrm{Y}$ direction (Fig. 5e) also point to a pure shear-dominated transpressional environment, with the nucleation and development of conjugate faults under decreasing $\mathrm{T}$ conditions and coupled exhumation.

Steeply plunging lineations are observable, in the syntectonic Maldonado Granite of the Aiguá Batholith, where oblate enclaves indicate intense flattening (pure sheardominated magmatic deformation). The coexistence of vertical and horizontal lineations in a shear zone could indicate an evolution from early vertical to late horizontal stretching lineations as described in the Rosy Finch-Gem Lake Shear Zone of Sierra Nevada by Tikoff and Greene (1997). However, the similar ages of the Maldonado granite $575 \pm 20$ (Umpierre and Halpern 1971) and the syntectonic muscovite of the quartz mylonites with shallow lineations (see age constraints), favors a partitioning of coeval simple shear-dominated and pure shear-dominated domains. Sullivan and Law (2007) demonstrated a similar 
partition of deformation domains in the White Mountain Shear Zone.

\section{Lithologies}

The most frequently observed lithology of the SBSZ is granitic mylonite. In most of the cases, the protoliths are syntectonic granites emplaced during the transcurrent event, with their margins transformed into mylonites during medium- to low-T deformation. Microstructures indicating transition from magmatic to solid-state deformation are frequently observed in these syntectonic granites. This relationship between shear zones and granitic intrusions in the DFB has been indicated by Tommasi et al. 1994, in case of the Dorsal de Canguçu SZ and is also observable in other belts, e.g. in the Periadriatic Line of the Alps (Rosenberg et al. 1995; Steenken et al. 2000; Rosenberg 2004 and references therein).

The confluence of shear zones, like SBSZ and CSZ in case of the Aiguá Batholith, could be a major factor controlling magma ascent and creating the space for the emplacement of large volumes of granitic magma, as pointed out for the Borborema Province in Brazil (Neves et al. 1996, 2000; Weinberg et al. 2004).

The influx of hydrous fluids is associated with the syntectonic breakdown of feldspar to mica in the granitic mylonites and their evolution to phyllonites. Strain was probably concentrated in these weakened zones, as in the case of the Outer Hebrides Fault Zone (Imber et al. 1997), the Median Tectonic Line of Japan (Jefferies et al. 2006) or the Great Glen Fault Zone (Stewart et al. 2000). The excess silica generated from the transformation reactions resulted in the emplacement of quartz veins that evolved into quartz mylonites. The fourth lithology is mylonitic porphyry, which resulted from the deformation of alkaline porphyries emplaced in the SBSZ as dikes.

Deformation mechanism and temperature constraints

Several aspects suggest that the exposed section of the SBSZ corresponds to an intermediate level of the crust: the low grade of metamorphism of associated deformed molassic sediments in the country rock, the porphyritic texture of the alkaline dikes and the microstructural features of the mylonites.

The microstructures present in quartz depend on the dislocation regime, which is in turn determined by the strain rate and the temperature (Hirth and Tullis 1992). At medium strain rates and temperatures, subgrain development predominates (regime 2). If the temperature increases or the strain rate decreases, grain boundary migration is dominant. The plastic behavior of quartz points to a minimum temperature condition of $\sim 270^{\circ} \mathrm{C}$ (Fitz Gerald and Stünitz 1993; van Daalen et al. 1999). In a recent detailed study of the eastern Tonale Fault, Stipp et al. (2002) established that in quartz, the transition from subgrain rotation to grain boundary migration recrystallization occurs at $\sim 500^{\circ} \mathrm{C}$. They also indicated that the strain rate in Tonale mylonites is within the range of most natural shear zones $\left(10^{-14}\right.$ to $10^{-11} \mathrm{~s}^{-1}$ ), concluding that the microstructural type can be used to estimate the temperature in mylonites when syntectonic paragenesis are not present. With respect to the microstructures of quartz observed in this investigation, the granitic mylonites predominantly display subgrain rotation recrystallization (regime 2). In the case of the quartz mylonites and the mylonitic porphyries, grain boundary migration in quartz is also an important recrystallization mechanism indicating deformation in the transition between regime 2 and regime 3 .

These microstructural criteria, together with the occurrence of stable biotite, indicate that the deformation in the mylonites of the SBSZ took place in lower amphibolite to upper greenschist facies conditions $\left(400-550^{\circ} \mathrm{C}\right)$, probably during decreasing $\mathrm{T}$ conditions through a protracted evolution. However, in the mylonitic porphyries, recrystallization is frequently important in feldspar, pointing to higher temperatures (400-650'; Tullis 2002) and suggesting magmatic or high-T solid-state deformation during cooling of the dikes. The observed medium temperature conditions of deformation in a regional low-grade crust are ascribed to heat provided by emplacement of the synkinematic intrusions.

\section{Age constraints}

Based on U-Pb SHRIMP dating on zircon from basement rocks of the DFB in southern Brazil, Leite et al. (2000) established the age for the high-K calc-alkaline protolith of the gneisses at around $2.08 \mathrm{Ga}$. These authors interpret younger ages in the range $800-590 \mathrm{Ma}$, in rims of zircons, as representing Neoproterozoic reworking, and suggested that the low-angle fabric in the gneisses formed close to $800 \mathrm{Ma}$, but stressed that further investigation is required. High temperature deformation of Neoproterozoic age has also been recognized elsewhere in Brazil in the Ribeira Belt (Egidio-Sylva et al. 2002; Hippert et al. 2001) and in the DFB (Fernandes et al. 1992; Tommasi et al. 1994; Gross et al. 2006). Given the available data for the region and the correlation with similar Neoproterozoic events in southern Brazil, the high temperature deformation that affected the pre-Brasiliano basement of the study area is 
postulated as probably Neoproterozoic in age. The regional extent of this high temperature deformation in Uruguay and Brazil indicates that it probably relates to a collision between large crustal plates (Leite et al. 2000) or to a thermal anomaly in the mantle in an intraplate setting (Neves et al. 2008).

The onset of the transpressional deformation is not easy to constrain. Frantz et al. (2003) reported ages ranging from 658 to $605 \mathrm{Ma}$ (SHRIMP U-Pb on zircon) for the Pelotas Batholith of Rio Grande do Sul, interpreted as synchronous with the transcurrent Dorsal de Canguçu Shear Zone. Recently, a new $\mathrm{Pb}-\mathrm{Pb}$ age on titanite of $614 \pm 3 \mathrm{Ma}$ was obtained for the Aiguá Batholith in the study area (Oyhantçabal et al. 2007), supporting a similar time interval for the syntectonic intrusions of the SBSZ.

An extensional or transtensional episode, with an age of ca. $590 \mathrm{Ma}$, is recorded in doleritic dikes (striking $020^{\circ}$ ) associated with molassic basins containing shoshonitic basaltic flows (Oyhantçabal et al. 2007; Pecoits et al. 2008). Two main transpressional episodes can be separated from this extensional event: (1) an early, associated with the nucleation of conjugate shear zones, and (2) a late event, associated with sinistral reactivation of the northsouth shear zones.

The minimum age of the second transpressional episode is constrained by the ${ }^{40} \mathrm{Ar} /{ }^{39} \mathrm{Ar}$ cooling age on muscovite from a quartz mylonite presented in this study $(586 \pm 2 \mathrm{Ma})$. Furthermore, the age of the alkaline magmatism associated with the mylonitic porphyries is ca. $579 \pm 1.5 \mathrm{Ma}\left({ }^{40} \mathrm{Ar} /{ }^{39} \mathrm{Ar}\right.$ in hornblende, Oyhantçabal et al. 2007). This concurs with the U-Pb ages ranging from 572 to $580 \mathrm{Ma}$ obtained for the alkaline felsic magmatism in Uruguay and Rio Grande do Sul (Leite et al. 1998; Chemale et al. 2003; Remus et al. 1999; Hartmann et al. 2002). These data indicate cooling and closure of muscovite was followed by syntectonic emplacement and deformation of the younger synkinematic granites and that tranpressional deformation occurred over a long time span. The lack of undeformed lithologies cutting the shear zone did not allow us to constrain the cessation of the transpressional deformation.

Available information suggest that the high- $T$ deformation of the basement (D1) is older than $658 \mathrm{Ma}$ and that a second phase (D2) associated with the onset of transcurrent shear and the emplacement of the intrusions of the Aiguá Batholith was probably protracted and took place between 658 and 600 Ma. After an extensional event (D3; $\sim 590 \mathrm{Ma}$ ), another transcurrent phase (D4) took place around $>586$ to $<560 \mathrm{Ma}$, which is responsible for the present structural arrangement of the SBSZ. The proposed evolution according to available structural and geochronological data is summarized in Table 2 and schematically shown in Fig. 9.

\section{Conclusions}

The SBSZ is part of a major shear system in the DFB. It is composed of north-south and southwest-northeast branches, and is responsible for the present architecture of most lithological units. Available geochronological data and structural observations indicate two main transpressional events: the first took place at $\sim 658-600 \mathrm{Ma}$ and is associated with nucleation and evolution of conjugate vertical shear zones, while the second event, at $>580$ to $<560 \mathrm{Ma}$, is associated with sinistral reactivation of the north-south branches.

The main features of the SBSZ can be summarized as follows: kinematic indicators demonstrate a sinistral sense of displacement with an eastside up component. Mylonitic granite is the most common lithology and developed from synkinematic granites during decreasing $\mathrm{T}$ conditions. Widespread associated lithologies, in contrast with the Dorsal de Canguçu shear zone, include phyllonites and quartz mylonites, probably derived from alteration of feldspar to mica and coupled with the release of silica. Additionally, subvolcanic dikes emplaced in the shear zone and evolved to mylonitic porphyries during shearing. The deformation took place

Table 2 Summary of the proposed evolution stages of the Sierra Ballena Shear Zone and available age constrains

\begin{tabular}{|c|c|c|c|}
\hline Age (Ma) & Phase & Event & Age constrains \\
\hline$>658$ & $\mathrm{D}_{1}$ & High-T deformation & Leite et al. (1998) \\
\hline $658-600$ & $\mathrm{D}_{2}$ & $\begin{array}{l}\text { Transpression, conjugate shear zones. } \\
\text { Syn-transcurrent magmatism }\end{array}$ & $\begin{array}{l}\text { Frantz et al. (2003), Babinski et al. (1997), } \\
\text { Philipp and Machado (2005), Oyhantçabal et al. (2007) }\end{array}$ \\
\hline$\sim 590$ & $\mathrm{D}_{3}$ & $\begin{array}{l}\text { Extension: mafic dikes (strike } 040^{\circ} \text { ) and } \\
\text { molassic basins }\end{array}$ & Janikian et al. (2008) \\
\hline$>586$ to $<576$ & $\mathrm{D}_{4}$ & $\begin{array}{l}\text { Sinistral transpression. Calc-alkaline and } \\
\text { alkaline magmatism }\end{array}$ & $\begin{array}{l}\text { Basei et al. (2000), Oyhantçabal et al. (2007) and this } \\
\text { investigation }\end{array}$ \\
\hline
\end{tabular}


Fig. 9 Proposed evolution stages. SYSZ Sarandí del Yí Shear Zone, SBSZ Sierra Ballena Shear Zone, CSZ Cordillera Shear Zone, $b$ doleritic dikes

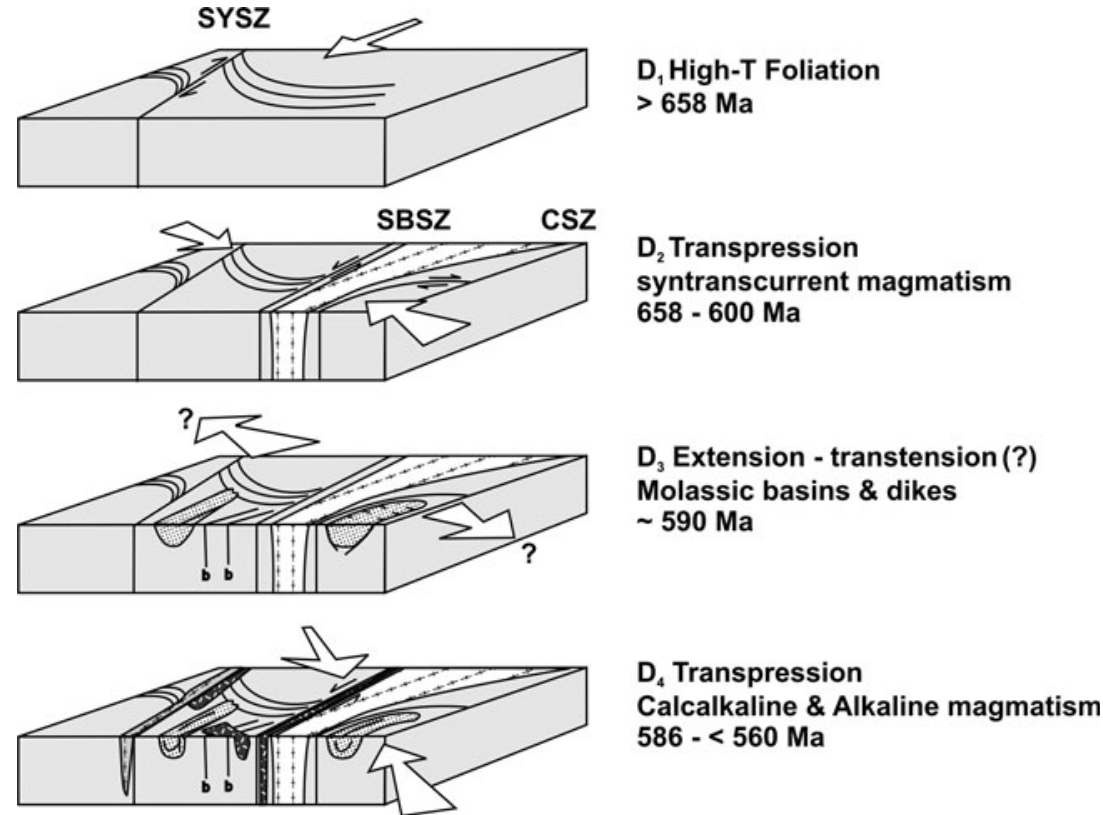

under lower amphibolite to upper greenschist facies metamorphic conditions, as shown by microstructures in quartz characteristic of the transition between dislocation creep regime 2 and 3 and the presence of stable biotite.

Acknowledgments Constructive reviews by Alain Vauchez and Kerstin Saalmann are greatly appreciated. The authors are indebted to Adriana Heimann, André Steenken, Pablo Lara and Fernando Hongn for their helpful comments. Many thanks go to Neil Mancktelow for his critical review of a previous version of the manuscript and to Carol Simpson for comments on the microstructures related to fluid-assisted grain boundary diffusion. P. Oyhantçabal gratefully acknowledges grants provided by the German Academic Exchange Service (DAAD, proposal A/06/00572) the German Science Foundation (DFG, GZ: SI 438/32-1) and CSIC-UdelaR (Comisión Sectorial de Investigación Científica de la Universidad de la República) for research stays at the Geoscience Centre of the Georg-August University Göttingen.

\section{Appendix}

${ }^{40} \mathrm{Ar} /{ }^{39} \mathrm{Ar}$ determinations

Ar-Ar determinations were conducted at the University of Alabama Geochronology Laboratory. The monitor mineral MMhb-1 (Samson and Alexander 1987) with an age of 513.9 Ma (Lanphere and Dalrymple 2000) was used to monitor neutron flux (and calculate the irradiation parameter, $J$ ). The samples and standards were wrapped in aluminum foil and loaded into aluminum holders of $2.5 \mathrm{~cm}$ diameter and $6 \mathrm{~cm}$ height. The samples were irradiated in position $5 \mathrm{c}$ of the uranium enriched research reactor of McMaster University in Hamilton, Ontario, Canada for $20 \mathrm{MW} \mathrm{h}$.

Upon their return from the reactor, the samples and monitors were loaded into $2 \mathrm{~mm}$ diameter holes in a copper tray that was then loaded in an ultra-high vacuum extraction line. The monitors were fused, and samples heated, using a 6-watt argon-ion laser following the technique described in York et al. (1981), Layer et al. (1987) and Layer (2000). Argon purification was achieved using a liquid nitrogen cold trap and a SAES Zr-Al getter at $400^{\circ} \mathrm{C}$. The samples were analyzed in a VG-3600 mass spectrometer at the Geophysical Institute, University of Alaska Fairbanks. The argon isotopes measured were corrected for system blank and mass discrimination, as well as calcium, potassium and chlorine interference reactions following procedures outlined in McDougall and Harrison (1999). System blanks generally were $2 \times 10^{-16} \mathrm{~mol}{ }^{40} \mathrm{Ar}$ and $2 \times 10^{-18} \mathrm{~mol}{ }^{36} \mathrm{Ar}$, which are $10-50$ times smaller than the fraction volumes. Mass discrimination was monitored by running both calibrated air shots and a zero-age glass sample. These measurements were made on a weekly to monthly basis to check for changes in mass discrimination (Table 3). 


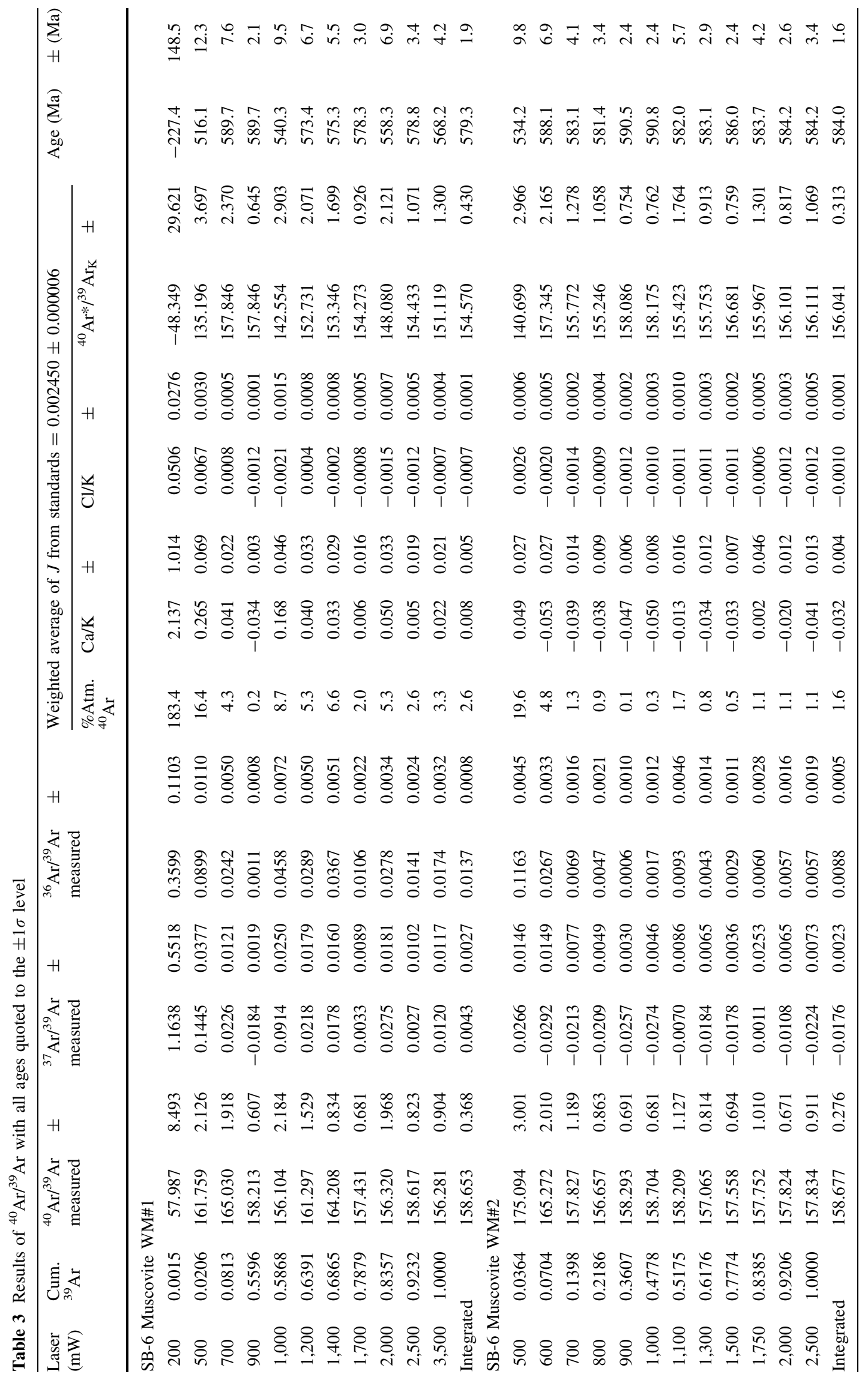




\section{References}

Babinski M, Chemale F Jr, Van Schmus WR, Hartmann LA, da Silva LC (1997) U-Pb and Sm-Nd geochronology of the Neoproterozoic Granitic-Gneissic Dom Feliciano Belt, Southern Brazil. J S Am Earth Sci 10:263-274. doi:10.1016/S0895-9811(97)00021-7

Basei MAS, Siga O Jr, Masquelin H, Harara OM, Reis Neto JM, Preciozzi F (2000) The Dom Feliciano Belt (Brazil-Uruguay) and its Foreland (Río de la Plata Craton): framework, tectonic evolution and correlations with similar terranes of southwestern Africa. In: Cordani U, Milani E, Thomaz Filho A, Campos D (eds) Tectonic evolution of South America. 31 IGC, Rio de Janeiro, pp 311-334

Basei MAS, Frimmel HE, Nutman AP, Preciozzi F, Jacob J (2005) A connection between the Neoproterozoic Dom Feliciano (Brazil/ Uruguay) and Gariep (Namibia/South Africa) orogenic beltsevidence from a reconnaissance provenance study. Precambrian Res 139:195-221. doi:10.1016/j.precamres.2005.06.005

Basei MAS, Frimmel HE, Nutman AP, Preciozzi F (2006) Provenance and Depositional Age of the Dom Feliciano Belt Supracrustal Units, Brazil, Uruguay: correlations with SW Africa. Short Papers V South American Symposium Isotopic Geology 45-48. Punta del Este, Uruguay

Basei MAS, Frimmel HE, Nutman AP, Preciozzi F (2008) West Gondwana amalgamation based on detrital zircon ages from Neoproterozoic Ribeira and Dom Feliciano belts of South America and comparison with coeval sequences from SW Africa. In: Pankhurst RJ, Trouw RAJ, Brito Neves BB, De Wit MJ (eds) West Gondwana: Pre-Cenozoic correlations across the South Atlantic Region. Geological Society, London, Special Publications 294, pp 239-256

Berthé D, Choukroune P, Jegouzo P (1979) Orthogneiss, mylonite and noncoaxial deformation of granite: the example of the South Armorican Shear Zone. J Struct Geol 1:31-42. doi:10.1016/ 0191-8141(79)90019-1

Bitencourt MF, Nardi LVS (2000) Tectonic setting and sources of magmatism related to the southern Brazilian shear belt. Rev Bras Geoc 30:186-189

Bossi J, Gaucher C (2004) The Cuchilla Dionisio Terrane, Uruguay: an allochthonous block accreted in the Cambrian to SWGondwana. Gondwana Res 7:661-674. doi:10.1016/S1342-937X (05)71054-6

Bossi J, Navarro R (1988) Serpentinitas cromíferas pre-orogénicas en el Ciclo Orogénico Moderno de Uruguay. Actas 6 Panel Geología Litoral-1 Reunión de Geología del Uruguay, Salto, Uruguay, pp 91-95

Boullier AM, Bouchez JL (1978) Le quartz en rubans dans les mylonites. Bull Soc Geol Fr 7:253-262

Campal N, Schipilov A (1999) The eastern edge of the Río de La Plata Craton: a history of tangential collisions. In: Sinha AK (Ed) Basement tectonics, vol 13, Kluwer Academic Publishers, Dordrecht, pp 33-48. ISBN 9780792354697

Chemale F Jr, Mallmann G, Bitencourt MF, Kawashita K (2003) Isotope geology of syntectonic magmatism along the Major Gercino Shear Zone, southern Brazil: implications for the timing of deformational events. Short Papers-IV South American Symposium on Isotope Geology, Salvador, Brazil, pp 516-519

D'lemos RS, Brown M, Strachan RA (1992) Granite magma generation, ascent and emplacement within a transpressional orogen. J Geol Soc Lond 149:487-490

da Silva LC, McNaughton NJ, Armstrong R, Hartmann LA, Fletcher IR (2005) The Neoproterozoic Mantiqueira Province and its African connections: a zircon-based U-Pb geochronologic subdivision for the Brasiliano/Pan-African systems of orogens. Precambrian Res 136:203-240. doi:10.1016/j.precamres.2004.10.004 de Saint Blanquat M, Tikoff B, Teyssier C, Vigneresse JL (1998) Transpressional kinematics and magmatic arcs. In: Holdsworth RE, Strachan RA, Dewey JF (eds) Continental transpressional and transtensional tectonics, vol 135. Geological Society Special Publication, London, pp 327-340

Dell'Angelo LN, Tullis J, Yund RA (1987) Transition from dislocation creep to melt-enhanced diffusion creep in fine grained granitic aggregates. Tectonophysics 139:325-332. doi:10.1016/ 0040-1951(87)90107-7

Dürr SB, Dingeldey DP (1996) The Kaoko belt (Namibia): part of a late Neoproterozoic continental-scale strike-slip system. Geology 24:503-506. doi:10.1130/0091-7613(1996)024<0503:TKBNPO> 2.3.CO;2

Egidio-Sylva M, Vauchez A, Bascou J, Hippert J (2002) High temperature deformation in the Neoproterozoic transpressional Ribeira belt, southeast Brazil. Tectonophysics 352:203-224. doi: 10.1016/S0040-1951(02)00197-X

Fernandes LAD, Koester E (1999) The Neoproterozoic Dorsal de Canguçu strike-slip shear zone: its nature and role in the tectonic evolution of southern Brazil. J Afr Earth Sci 29:3-24. doi: 10.1016/S0899-5362(99)00076-7

Fernandes LAD, Tommasi A, Porcher CC (1992) Deformation patterns in the southern Brazilian branch of the Dom Feliciano Belt: a reappraisal. J S Am Earth Sci 5:77-96. doi:10.1016/ 0895-9811(92)90061-3

Fernandes LAD, Tommasi A, Vauchez A, Porcher CC, Menegat R, Koester E (1993) Zona de Cisalhamento transcorrente Dorsal de Canguçu: Caracterização e importância na compartimentação tectônica do Cinturão Dom Feliciano. Rev Bras Geoc 23:1-10

Fitz Gerald JD, Stünitz H (1993) Deformation of granitoids at low metamorphic grade. I: Reactions and grain size reduction. Tectonophysics 221:269-297. doi:10.1016/0040-1951(93) 90163-E

Frantz JC, McNaughton NJ, Marques JC, Hartmann LA, Botelho NF, Caravaca G (2003) Shrimp U-Pb zircon ages of granitoids from southernmost Brazil: constraints on the temporal evolution on the Dorsal de Canguçu transcurrent shear zone and the eastern Dom Feliciano Belt. IV South American Symposium Isotope Geology, pp 174-177

Garlick SR, Gromet LP (2004) Diffusion creep and partial melting in high temperature mylonitic gneisses, Hope Valley shear zone, New England Appalachians, USA. J Metamorph Geol 22:45-61. doi:10.1111/j.1525-1314.2004.00496.x

Gaucher C (2000) Sedimentology, palaeontology and stratigraphy of the Arroyo del Soldado Group (Vendian to Cambrian, Uruguay). Beringeria 26:1-120

Gaucher C, Boggiani PC, Sprechmann P, Sial AN, Fairchild T (2003) Integrated correlation of the Vendian to Cambrian Arroyo del Soldado and Corumbá Groups (Uruguay and Brazil): palaeogeographic, palaeoclimatic and palaeobiologic implications. Precambrian Res 120:241-278. doi:10.1016/S0301-9268(02) 00140-7

Gaucher C, Chiglino L, Pecoits E (2004) Southernmost exposures of the Arroyo del Soldado Group (Vendian to Cambrian, Uruguay): paleogeographic implications for the amalgamation of W.-Gondwana. Gondwana Res 7:701-714. doi:10.1016/S1342937X(05)71057-1

Ghosh SK, Chatterjee A (1985) Patterns of deformed early lineations over later folds formed by buckling and flattening. J Struct Geol 7:651-666. doi:10.1016/0191-8141(85)90141-5

Goscombe BD, Gray DR (2008) Structure and strain variation at midcrustal levels in a transpressional orogen: a review of Kaoko Belt structure and the character of West Gondwana amalgamation and dispersal. Gondwana Res 13:45-85. doi:10.1016/j.gr.2007. 07.002 
Gower RJW, Simpson C (1992) Phase boundary mobility in naturally deformed, high grade quartzo-feldspathic rocks: evidence for diffusional creep. J Struct Geol 14:301-313. doi:10.1016/01918141(92)90088-E

Gross AOMS, Porcher CC, Fernandes LAD, Koester E (2006) Neoproterozoic low-pressure/high-temperature collisional metamorphic evolution in the Varzea do Capivarita Metamorphic Suite, SE Brazil: thermobarometric and $\mathrm{Sm} / \mathrm{Nd}$ evidence. Precambrian Res 147:41-64. doi:10.1016/j.precamres.2006.02. 001

Harries D, Ewiak O, Kienast M, Löbens S, Prechtel F, Ertl G, Bense F, Oyhantçabal P, Siegesmund S, Wemmer K (2007) A geological map of the Sierra Balllena Shear zone and its western basement, northeast of Villa Serrana, Dom Feliciano Belt, Uruguay. V Congreso Uruguayo Geología, CD-ROM, Montevideo

Hartmann LA, Campal N, Santos JO, McNaughton N, Bossi J, Schipilov A, Lafon JM (2001) Archean crust in the Río de la Plata Craton, Uruguay-SHRIMP U-Pb zircon reconnaissance geochronology. J S Am Earth Sci 14:557-570. doi:10.1016/ S0895-9811(01)00055-4

Hartmann LA, Santos JO, Bossi J, Campal N, Schipilov A, McNaughton N (2002) Zircon and Titanite U-Pb SHRIMP geochronology of Neoproterozoic felsic magmatism on the eastern border of the Río de la Plata Craton, Uruguay. J S Am Earth Sci 15:229-236. doi:10.1016/S0895-9811(02)00030-5

Hemley JJ, Jones WR (1964) Chemical aspects of hydrothermal alteration with emphasis on hydrogen metasomatism. Econ Geol 59:538-569. doi:10.2113/gsecongeo.59.4.538

Hippert J (1999) Are S-C structures, duplexes and conjugate shear zones different manifestations of the same scale-invariant phenomenon? J Struct Geol 21:975-984. doi:10.1016/S01918141(99)00047-4

Hippert J, Rocha A, Lana C, Egydio-Silva M, Takeshita T (2001) Quartz plastic segregation and ribbon development in high-grade striped gneisses. J Struct Geol 23:67-80. doi:10.1016/S01918141(00)00129-2

Hirth G, Tullis J (1992) Dislocation creep regimes in quartz aggregates. J Struct Geol 14:145-159. doi:10.1016/0191-8141 (92)90053-Y

Hirth G, Dunlap WJ, Teyssier CP (1998) Dislocation creep regimes in naturally deformed quartz aggregates. In: Snoke AW, Tullis J, Todd VR (eds) Fault-related rocks, a photographic atlas. Princeton University Press, NJ, pp 500-501, 617

Hutton DHW, Reavy RJ (1992) Strike-slip and granite petrogenesis. Tectonics 11:960-967. doi:10.1029/92TC00336

Hutton DHW, Siegesmund S (2001) The Ardara Granite: reinflating the balloon hypothesis. Z Dtsch Ges Geowissenschaften 152:309-323

Imber J, Holdsworth RE, Butler CA, Lloyd GE (1997) Fault-zone weakening processes along the reactivated Outer Hebrides Fault Zone, Scotland. J Geol Soc London 154:105-109. doi:10.1144/ gsjgs.154.1.0105

Janikian L, Paes de Almeida R, Ferreira da Trindade RI, FragosoCesar ARS, D'Agrella-Filho MS, Dantas EL, Tohver E (2008) The continental record of Ediacaran volcano-sedimentary successions in southern Brazil and their global implications. Terra Nova 20:259-266. doi:10.1111/j.1365-3121.2008.00814.x

Jefferies SP, Holdsworth RE, Wibberley CAJ, Shimamoto T, Spiers CJ, Niemeijer AR, Lloyd GE (2006) The nature and importance of phyllonite development in crustal-scale fault cores: an example from the Median Tectonic Line, Japan. J Struct Geol 28:220-235. doi:10.1016/j.jsg.2005.10.008

Jeng FS, Lu CY, Huang KP (2007) Factors affecting transpressional folding as inferred from numerical analysis. Terr Atmos Ocean Sci 18:645-669
Kruhl JH (1996) Prism- and basal-plane parallel subgrain boundaries in quartz: a microstructural geothermometer. J Metamorph Geol 14:581-589. doi:10.1046/j.1525-1314.1996.00413.x

Lanphere MA, Dalrymple GB (2000) First-principles calibration of ${ }^{38} \mathrm{Ar}$ tracers: implications for the ages of ${ }^{40} \mathrm{Ar} /{ }^{39} \mathrm{Ar}$ fluence monitors. U.S. Geological Survey Professional Paper 1621, p 10

Layer PW (2000) Argon-40/argon-39 age of the El'gygytgyn impact event, Chukotka, Russia. Meteorit Planet Sci 35:591-599

Layer PW, Hall CM, York D (1987) The derivation of ${ }^{40} \mathrm{Ar} /{ }^{39} \mathrm{Ar}$ age spectra of single grains of hornblende and biotite by laser step heating. Geophys Res Lett 14:757-760. doi:10.1029/GL014i007 p00757

Leite JAD, Hartmann LA, McNaughton NJ, Chemale F Jr (1998) SHRIMP U/Pb zircon geochronology of Neoproterozoic juvenile and crustal-reworked terranes in southernmost Brazil. Int Geol Rev 40:688-705

Leite JAD, Hartmann LA, Fernandes LAD, McNaughton NJ, Soliani E Jr, Koester E, Santos JOS, Vasconcellos MAZ (2000) Zircon $\mathrm{U}-\mathrm{Pb}$ SHRIMP dating of gneissic basement of the Dom Feliciano Belt, southern Brazil. J S Am Earth Sci 13:739-750. doi: 10.1016/S0895-9811(00)00058-4

Mallmann G, Chemale F Jr, Armstrong R, Kawashita K (2003) Sm$\mathrm{Nd}$ and U-Pb Shrimp Zircon studies of the Nico Pérez Terrane, Reworked Río de la Plata Craton, Uruguay. Short Papers-IV South American Symposium on Isotope Geology, Salvador, Brazil

Masquelin H (2004) El Complejo Cerro Olivo, Sureste de Uruguay: una revisión estratigráfica y tectónica. IV Congreso Uruguayo Geología, CD-ROM, Montevideo

Masquelin H, Silva AOM, Porcher CC, Fernandes LAD, Morales E (2001) Geología y Geotermobarometría de la Suite Metamórfica Chafalote, Basamento Prebrasiliano, Sureste del Uruguay. XI Congreso Latinoamericano Geología, Montevideo, Actas, CDROM

Masquelin H, Morales E, Piñeiro G (2002) Geología de las rocas calcosilicatadas de la suite parametamórfica Chafalote, sudeste del Uruguay. Actas XV Congreso Geológico Argentino, El Calafate

McDougall I, Harrison TM (1999) Geochronology and thermochronology by the ${ }^{40} \mathrm{Ar} /{ }^{39} \mathrm{Ar}$ method, 2nd edn. Oxford University Press, New York, p 269

Moores EM, Twiss RJ (1995) Tectonics. Freeman, San Francisco, p 415

Mulch A, Cosca MA (2004) Recrystallization or cooling ages? In situ UV-laser 40Ar/39Ar geochronology of muscovite in mylonitic rocks. J Geol Soc London 161:573-582. doi:10.1144/0016764903-110

Neves SP, Vauchez A, Archanjo CJ (1996) Shear zone-controlled magma emplacement or magma-assisted nucleation of shear zones? Insights from northeast Brazil. Tectonophysics 262:349 364. doi:10.1016/0040-1951(96)00007-8

Neves SP, Vauchez A, Feraud G (2000) Tectono-thermal evolution, magma emplacement, and shear zone development in the Caruaru area (Borborema Province, NE Brazil). Precambrian Res 99:1-32. doi:10.1016/S0301-9268(99)00026-1

Neves SP, Tommasi A, Vauchez A (2008) Intraplate continental deformation: influence of a heat-producing layer in the lithospheric mantle. Earth Planet Sci Lett 274:392-400. doi: 10.1016/j.epsl.2008.07.040

Nilsen TH, Sylvester AG (1995) Strike-slip basins. In: Busby CJ, Ingersoll RV (eds) Tectonics of sedimentary basins. Blackwell, Oxford, pp 425-457

Oyhantçabal P (2005) The Sierra Ballena Shear zone: kinematics, timing and its significance for the geotectonic evolution of southeast Uruguay. http://webdoc.sub.gwdg.de/diss/2005/ oyhantcabal_cironi/oyhantcabal_cironi.pdf 
Oyhantçabal P, Siegemund S, Wemmer K, Frei R, Layer P (2007) Post-collisional transition from calc-alkaline to alkaline magmatism during transcurrent deformation in the southernmost Dom Feliciano Belt (Braziliano-Pan-African, Uruguay). Lithos 98:141-159. doi:10.1016/j.lithos.2007.03.001

Passchier CW (1987) Stable positions of rigid objects in non-coaxial flow-a study in vorticity analysis. J Struct Geol 9:679-690. doi: 10.1016/0191-8141(87)90152-0

Passchier CW, Trouw RAJ (1996) Microtectonics. Springer, Berlin, p 289

Pecoits E, Aubet N, Oyhantçabal P, Sánchez Bettucci L (2004) Estratigrafía de Sucesiones Sedimentarias y volcanosedimentarias Neoproterozoicas del Uruguay. Rev Soc Uruguaya Geol $11: 18-27$

Pecoits E, Gingras M, Aubet N, Konhauser K (2008) Ediacaran in Uruguay: palaeoclimatic and palaeobiological implications. Sedimentology 55:689-719. doi:10.1111/j.1365-3091.2007.00918.x

Philipp RP, Machado R (2005) The Late Neoproterozoic granitoid magmatism of the Pelotas Batholith, southern Brazil. J S Am Earth Sci 19:461-478. doi:10.1016/j.jsames.2005.06.010

Platt JP, Vissers RLM (1980) Extensional structures in anisotropic rocks. J Struct Geol 2:397-410. doi:10.1016/0191-8141(80) 90002-4

Porada H (1989) Pan-African rifting and orogenesis in southern equatorial Africa and eastern Brazil. Precambrian Res 44:103136. doi:10.1016/0301-9268(89)90078-8

Porcher CA (2000) Programa Levantamentos Geológicos Básicos do Brasil. Cachoeira do Sul, Folha SH.22-Y-A. Estado do Rio de Grande do Sul. Escala 1:250.000. CPRM, Brasília CD-ROM

Powell RE (1992) Evolution of the San Andreas fault. Annu Rev Earth Planet Sci 20:431-468. doi:10.1146/annurev.ea.20.050192. 002243

Preciozzi F, Masquelin H, Basei MAS (1999) The Namaqua/ Grenville terrane of eastern Uruguay. II South American symposium isotopic geology, Carlos Paz, Argentina

Ramgrab GE (1999) Programa Levantamentos Geológicos Básicos do Brasil-PLGB: Pedro Osório. SH.22-Y-C. Estado do Rio Grande do Sul. Escala 1:250.000. CPRM, Brasília CD-ROM

Ramsay JG (1980) Shear zone geometry: a review. J Struct Geol 2:83-99. doi:10.1016/0191-8141(80)90038-3

Ramsay JG (1982) Rock ductility and its influence on the development of tectonic structures in mountain belts. In: Hsü KJ (ed) Mountain building processes. Academic Press, London, pp 11128

Remus MVD, Hartmann LA, McNaughton NJ, Fletcher IR (1999) SHRIMP U-Pb zircon ages of volcanism from the Sao Gabriel Block, southern Brazil. Boletim de Resumos. I Simposio sobre Vulcanismo e Ambientes Associados 89, Gramado

Rosenberg CL (2004) Shear zones and magma ascent: a model based on a review of the Tertiary magmatism in the Alps. Tectonics 23:1-21. doi:10.1029/2003TC001526

Rosenberg CL, Berger A, Schmid SM (1995) Observations from the floor of a granitoid pluton: inferences on the driving force of final emplacement. Geology 23:443-446. doi:10.1130/00917613(1995)023<0443:OFTFOA > 2.3.CO;2

Saalmann K, Remus MVD, Hartmann LA (2006) Tectonic evolution of the Neoproterozoic Sao Gabriel block, southern Brazil: constraints on Brasiliano orogenic evolution of the Río de la Plata cratonic margin. J S Am Earth Sci 21:204-227. doi: 10.1016/j.jsames.2006.05.003

Samson SD, Alexander EC (1987) Calibration of the interlaboratory ${ }^{40} \mathrm{Ar} /{ }^{39} \mathrm{Ar}$ dating standard, MMhb1. Chem Geol Isot Geosci Sect 66:27-34. doi:10.1016/0168-9622(87)90025-X

Sánchez-Bettucci L, Ramos V (1999) Aspectos Geológicos de las rocas metavulcánicas y metasedimentarias del Grupo Lavalleja, Sudeste de Uruguay. Rev Bras Geocienc 29:557-570
Sánchez-Bettucci L, Cosarinsky M, Ramos VA (2001) Tectonic setting of the late Proterozoic Lavalleja Group (Dom Feliciano Belt), Uruguay. Gondwana Res 4:395-407. doi:10.1016/S1342937X(05)70339-7

Schmid SM, Aebli HR, Heller F, Zing A (1989) The role of the Periadriatic Line in the tectonic evolution of the Alps. In: Coward MP et al (eds) Alpine tectonics, vol 45. Geological Society Special Publication, London, pp 153-171

Sengör AMC, Tüysüz O, Imren C, Sakınç M, Eyidoğan H, Görür H, Le Pichon X, Rangin C (2005) The North Anatolian Fault: a new look. Annu Rev Earth Planet Sci 33:37-112. doi:10.1146/ annurev.earth.32.101802.120415

Sengupta S, Ghosh SK (2004) Analysis of transpressional deformation from geometrical evolution of mesoscopic structures from Phulad shear zone, Rajasthan, India. J Struct Geol 26:19611976. doi:10.1016/j.jsg.2004.05.002

Steenken A, Siegesmund S, Heinrichs T (2000) The emplacement of the Rieserferner Pluton (Eastern Alps, Tyrol): constraints from field observations, magmatic fabrics and microstructures. J Struct Geol 22:1855-1873. doi:10.1016/S0191-8141(00)00071-7

Steiger RH, Jaeger E (1977) Subcommission on geochronology: convention on the use of decay constants in geo and cosmochronology. Earth Planet Sci Lett 36:359-362. doi:10.1016/ 0012-821X(77)90060-7

Stewart M, Holdsworth RE, Strachan RA (2000) Deformation processes and weakening mechanisms within the frictional \pm viscous transition zone of major crustal-scale faults: insights from the Great Glen Fault Zone, Scotland. J Struct Geol 22:543-560. doi:10.1016/S0191-8141(99)00164-9

Stipp M, Stünitz H, Heilbronner R, Schmid SM (2002) The eastern Tonale fault zone: a 'natural laboratory' for crystal plastic deformation of quartz over a temperature range from 250 to $700^{\circ}$ C. J Struct Geol 24:1861-1884. doi:10.1016/S0191-8141 (02)00035-4

Sullivan WA, Law RD (2007) Deformation path partitioning within the transpressional White Mountain shear zone, California and Nevada. J Struct Geol 29:583-599. doi:10.1016/j.jsg.2006. 11.001

Teixeira AL, Gaucher C, Paim PSG, Fonseca MM, Parente CV, Silva Filho WF, Almeida AR (2004) Bacias do Estágio de Transição da Plataforma Sul-Americana. In: Mantesso-Neto V, Bartorelli A, Dal Ré Carneiro C, Brito Neves BB (eds) Geologia do Continente Sul-Americano: Evolução da obra de Fernando Flávio Marques de Almeida. Beca Produções Culturais, São Paulo, pp 487-537

Tikoff B, Greene DC (1997) Stretching lineations in transpressional shear zones: an example from the Sierra Nevada Batholith, California. J Struct Geol 19:29-39. doi:10.1016/S0191-8141 (96)00056-9

Tommasi A, Vauchez A, Fernándes LAD, Porcher CC (1994) Orogen-parallel strike-slip faulting and synkinematic magmatism in the Dom Feliciano Belt, Southern Brazil. Tectonics 13:421-437. doi:10.1029/93TC03319

Tullis J (2002) Deformation of granitic rocks: experimental studies and natural examples. In: Karato S-I, Wenk H-R (eds) Plastic deformation of minerals and rocks. Rev Mineral Geochem 51:51-95

Tullis J, Stünitz H, Teyssier C, Heilbronner R (2000) Deformation microstructures in quartzo-feldspathic rocks. In: Jessell MW, Urai JL (eds) Stress, strain and structure. A volume in honour of WD Means. J Virtual Explorer 2

Umpierre M, Halpern M (1971) Edades Sr-Rb del Sur de la República Oriental del Uruguay. Rev Assoc Geol Argent 26:133-155

van Daalen M, Heilbronner R, Kunze K (1999) Orientation analysis of localized shear deformation in quartz fibres at the 
brittle-ductile transition. Tectonophysics 303:83-107. doi: 10.1016/S0040-1951(98)00264-9

Wang E (1997) Displacement and timing along the northern strand of the Altyn Tagh fault zone, Northern Tibet. Earth Planet Sci Lett 150:55-64. doi:10.1016/S0012-821X(97)00085-X

Weinberg RF, Sial AN, Mariano G (2004) Close spatial relationship between plutons and shear zones. Geology 32:377-380. doi: 10.1130/G20290.1

Wibberley CAJ, McCaig AM (2000) Quantifying orthoclase and albite muscovitisation sequences in fault zones. Chem Geol 165:181-196. doi:10.1016/S0009-2541(99)00170-9
Yin A, Rumelhart PE, Butler R, Cowgill E, Harrison TM, Foster DA, Ingersoll RV et al (2002) Tectonic history of the Altyn Tagh fault system in northern Tibet inferred from Cenozoic sedimentation. Geol Soc Am Bull 114:1257-1295. doi:10.1130/00167606(2002)114<1257:THOTAT>2.0.CO;2

York D, Hall CM, Yanase Y, Hanes JA, Kenyon WJ (1981) ${ }^{40} \mathrm{Ar} /{ }^{39} \mathrm{Ar}$ dating of terrestrial minerals with a continuous laser. Geophys Res Lett 8:1136-1138. doi:10.1029/GL008i011p01136 